\title{
EFFECTS OF MANAGEMENT PRACTICES ON GRASSLAND BIRDS:
}

BURROWING OWL

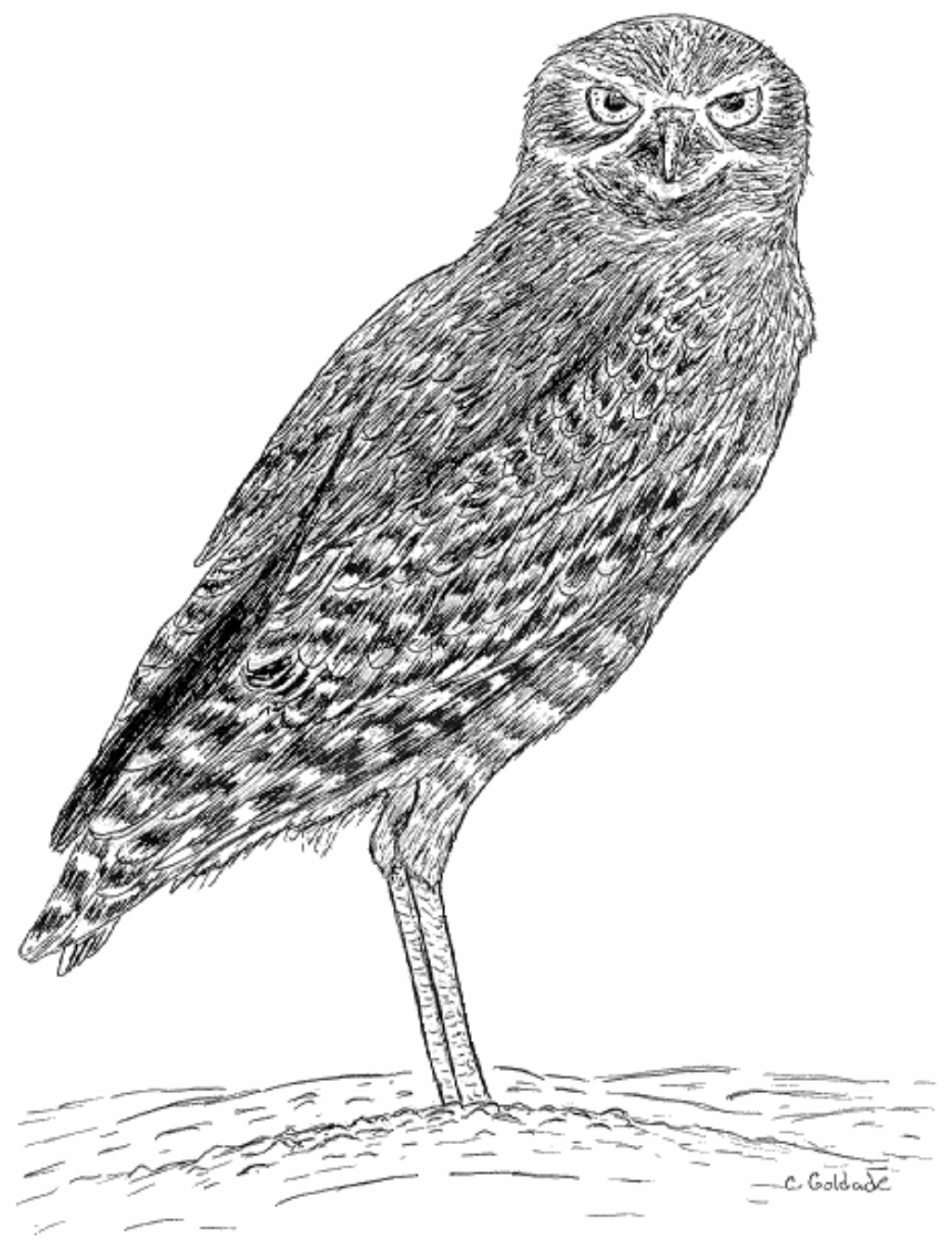

Grasslands Ecosystem Initiative

Northern Prairie Wildlife Research Center U.S. Geological Survey Jamestown, North Dakota 58401 
This report is one in a series of literature syntheses on North American grassland birds. The need for these reports was identified by the Prairie Pothole Joint Venture (PPJV), a part of the North American Waterfowl Management Plan. The PPJV recently adopted a new goal, to stabilize or increase populations of declining grassland- and wetland-associated wildlife species in the Prairie Pothole Region. To further that objective, it is essential to understand the habitat needs of birds other than waterfowl, and how management practices affect their habitats. The focus of these reports is on management of breeding habitat, particularly in the northern Great Plains.

Suggested citation:

Dechant, J. A., M. L. Sondreal, D. H. Johnson, L. D. Igl, C. M. Goldade, P. A. Rabie, and B. R. Euliss. 1999 (revised 2002). Effects of management practices on grassland birds: Burrowing Owl. Northern Prairie Wildlife Research Center, Jamestown, ND. 33 pages.

Species for which syntheses are available or are in preparation:

American Bittern
Mountain Plover
Marbled Godwit
Long-billed Curlew
Willet
Wilson's Phalarope
Upland Sandpiper
Greater Prairie-Chicken
Lesser Prairie-Chicken
Northern Harrier
Swainson's Hawk
Ferruginous Hawk
Short-eared Owl
Burrowing Owl
Horned Lark
Sedge Wren
Loggerhead Shrike
Sprague’s Pipit

Grasshopper Sparrow

Baird's Sparrow

Henslow's Sparrow

Le Conte's Sparrow

Nelson's Sharp-tailed Sparrow

Vesper Sparrow

Savannah Sparrow

Lark Sparrow

Field Sparrow

Clay-colored Sparrow

Chestnut-collared Longspur

McCown's Longspur

Dickcissel

Lark Bunting

Bobolink

Eastern Meadowlark

Western Meadowlark

Brown-headed Cowbird 


\section{EFFECTS OF MANAGEMENT PRACTICES ON GRASSLAND BIRDS: BURROWING OWL}

Jill A. Dechant, Marriah L. Sondreal, Douglas H. Johnson, Lawrence D. Igl, Christopher M. Goldade, Paul A. Rabie, and Betty R. Euliss

Series Coordinator: Douglas H. Johnson Series Assistant Coordinator: Lawrence D. Igl

Reviewers: Troy I. Wellicome, Martha J. Desmond, and Robert K. Murphy

Range Map: Jeff T. Price

Cover Art: Christopher M. Goldade

Major Funding: Prairie Pothole Joint Venture, U.S. Fish and Wildlife Service U.S. Geological Survey

Funding also provided by: U.S. Forest Service

The Nature Conservancy

\section{Collaborators:}

Louis B. Best, Iowa State University

Carl E. Bock, University of Colorado

Brenda C. Dale, Canadian Wildlife Service

Stephen K. Davis, Saskatchewan Wetland Conservation Corporation

James J. Dinsmore, Iowa State University

James K. Herkert, Illinois Endangered Species Protection Board

Fritz L. Knopf, Midcontinent Ecological Science Center

Rolf R. Koford, Iowa Cooperative Fish and Wildlife Research Unit

David R. C. Prescott, Alberta NAWMP Centre

Mark R. Ryan, University of Missouri

David W. Sample, Wisconsin Department of Natural Resources

David A. Swanson, Ohio Division of Wildlife

Peter D. Vickery, Massachusetts Audubon Society

John L. Zimmerman (retired), Kansas State University

March 1999

(revised January 2002) 


\section{ORGANIZATION AND FEATURES OF THIS SPECIES ACCOUNT}

Information on the habitat requirements and effects of habitat management on grassland birds were summarized from information in more than 4,000 published and unpublished papers. A range map is provided to indicate the relative densities of the species in North America, based on Breeding Bird Survey (BBS) data. Although birds frequently are observed outside the breeding range indicated, the maps are intended to show areas where managers might concentrate their attention. It may be ineffectual to manage habitat at a site for a species that rarely occurs in an area. The species account begins with a brief capsule statement, which provides the fundamental components or keys to management for the species. A section on breeding range outlines the current breeding distribution of the species in North America, including areas that could not be mapped using BBS data. The suitable habitat section describes the breeding habitat and occasionally microhabitat characteristics of the species, especially those habitats that occur in the Great Plains. Details on habitat and microhabitat requirements often provide clues to how a species will respond to a particular management practice. A table near the end of the account complements the section on suitable habitat, and lists the specific habitat characteristics for the species by individual studies. A special section on prey habitat is included for those predatory species that have more specific prey requirements. The area requirements section provides details on territory and home range sizes, minimum area requirements, and the effects of patch size, edges, and other landscape and habitat features on abundance and productivity. It may be futile to manage a small block of suitable habitat for a species that has minimum area requirements that are larger than the area being managed. The Brown-headed Cowbird (Molothrus ater) is an obligate brood parasite of many grassland birds. The section on cowbird brood parasitism summarizes rates of cowbird parasitism, host responses to parasitism, and factors that influence parasitism, such as nest concealment and host density. The impact of management depends, in part, upon a species' nesting phenology and biology. The section on breeding-season phenology and site fidelity includes details on spring arrival and fall departure for migratory populations in the Great Plains, peak breeding periods, the tendency to renest after nest failure or success, and the propensity to return to a previous breeding site. The duration and timing of breeding varies among regions and years. Species' response to management summarizes the current knowledge and major findings in the literature on the effects of different management practices on the species. The section on management recommendations complements the previous section and summarizes specific recommendations for habitat management provided in the literature. If management recommendations differ in different portions of the species' breeding range, recommendations are given separately by region. The literature cited contains references to published and unpublished literature on the management effects and habitat requirements of the species. This section is not meant to be a complete bibliography; a searchable, annotated bibliography of published and unpublished papers dealing with habitat needs of grassland birds and their responses to habitat management is posted at the Web site mentioned below.

This report has been downloaded from the Northern Prairie Wildlife Research Center WorldWide Web site, www.npwrc.usgs.gov/resource/literatr/grasbird/grasbird.htm. Please direct comments and suggestions to Douglas H. Johnson, Northern Prairie Wildlife Research Center, U.S. Geological Survey, 8711 37th Street SE, Jamestown, North Dakota 58401; telephone: 701253-5539; fax: 701-253-5553; e-mail: Douglas_H_Johnson@usgs.gov. 


\section{BURROWING OWL}

(Speotyto cunicularia hypugaea)

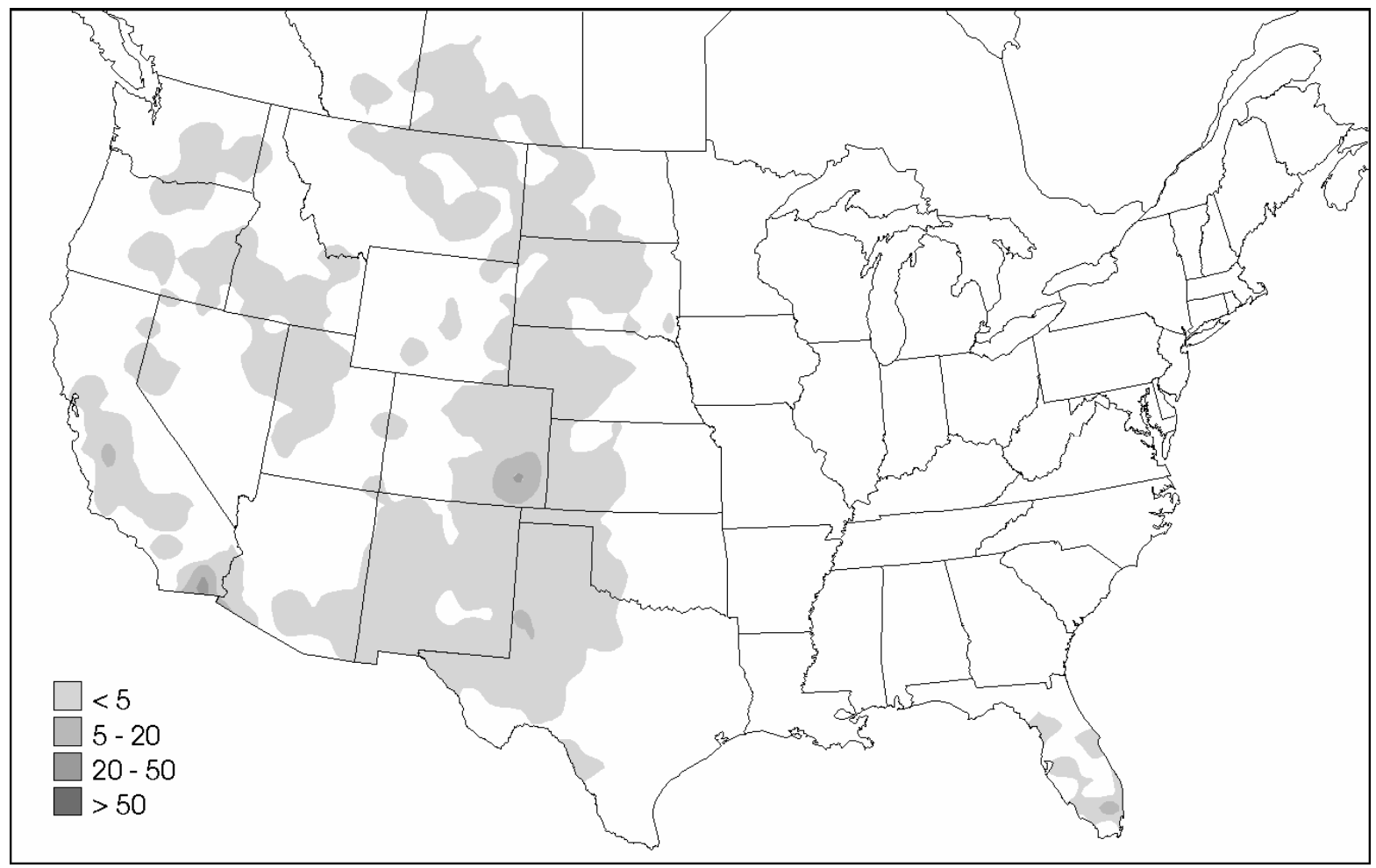

Figure. Breeding distribution of the Burrowing Owl in the United States and southern Canada, based on Breeding Bird Survey data, 1985-1991. Scale represents average number of individuals detected per route per year. Map from Price, J., S. Droege, and A. Price. 1995. The summer atlas of North American birds. Academic Press, London, England. 364 pages.

Keys to management include providing areas of short, sparse vegetation and maintaining populations of prey species and of burrowing mammals to ensure availability of burrows as nest sites. In particular, the conservation of black-tailed prairie dog (Cynomys ludovicianus) and Richardson's ground squirrel (Spermophilus richardsonii) colonies appears to be vital to the preservation of Burrowing Owls on the Great Plains.

\section{Breeding range:}

Two subspecies of Burrowing Owl breed in North America: the western Burrowing Owl (Speotyto cunicularia hypugaea) and the Florida Burrowing Owl (S. c. floridana). This account deals only with the subspecies of Burrowing Owl that breeds on the Great Plains, the western Burrowing Owl, and not with the Florida Burrowing Owl, which breeds in Florida. Western Burrowing Owls breed from southern Alberta to southwestern Saskatchewan, south through eastcentral Washington, central Oregon, and southern California, and east to eastern North Dakota, westcentral Kansas, and Texas. Populations in the northern part of this range are migratory (National Geographic Society 1987). (See figure for the relative densities of 
Burrowing Owls in the United States and southern Canada, based on Breeding Bird Survey data.)

Suitable habitat:

Burrowing Owls prefer open areas within deserts, grasslands, and shrubsteppe. They use well-drained, level to gently sloping areas characterized by sparse vegetation and bare ground such as moderately or heavily grazed pasture (Salt and Wilk 1958; Bent 1961; Grant 1963, 1965; James and Seabloom 1968; Stewart 1975; Wedgwood 1976; Haug 1985; MacCracken et al. 1985a; Haug and Oliphant 1987; Stockrahm 1995). Burrowing Owls breed in native prairie (Bent 1961, Butts 1973, Wedgwood 1976, Konrad and Gilmer 1984, Faanes and Lingle 1995, Clayton and Schmutz 1999), as well as in tame pasture, hayland, fallow fields, road and railway rights-of-way, and in a number of urban habitats (Scott 1940, Bue 1955, Hall 1961, Richards 1972, Butts 1973, Zarn 1974, Konrad and Gilmer 1984, Haug 1985, Haug and Oliphant 1987, James et al. 1990, Haug et al. 1993). Although Burrowing Owls occasionally nest in cropland (Grant 1965, Butts 1973, Schmutz and Moody 1989, John and Romanow 1993), most of these nests probably fail when the land is cultivated (T. I. Wellicome, University of Alberta, Edmonton, Alberta, pers. comm.). In northcentral Colorado, Burrowing Owls were uncommon in cultivated land (Olendorff 1973). In Alberta, fewer (41\% of 34) nest sites than non-nest sites (59\%) occurred within 0.5 km of cropland (Schmutz 1997). Clayton and Schmutz (1999) examined habitat selection of breeding owls in southeastern Alberta and on the Regina Plains, Saskatchewan. Land use was categorized into native pasture, re-seeded pasture, cultivation, and a miscellaneous category. All nest sites (100\% of 21 observations over 2 yr) in Alberta were located in native pasture. The majority of roost sites also were located in native pasture, with only $2 \%$ of 522 observations occurring in re-seeded pasture. Within pastures, Burrowing Owls preferred shorter $(\leq 10 \mathrm{~cm})$ grasses for both nesting and roosting. In the Regina Plain, nest sites and roost sites were nearly equally divided between native pasture and re-seeded pasture. Reseeded pastures were selected over native pastures for roosting when availability of the different landuses was considered. In cropland, owls did not selectively nest in short grass, but also nested in strips of medium to tall grass between fields and near ponds, granaries, and roads, possibly because suitable habitat was lacking. Although owls used short grass for nesting and roosting, they foraged over areas of tall vegetation.

Burrowing Owls on the Great Plains are not known to dig their own burrows, and usually rely on burrowing mammals to excavate nest sites (Salt and Wilk 1958; Bent 1961; Berdan and Linder 1973; Stewart 1975; Wedgwood 1976; Desmond 1991; Haug et al. 1993; Stockrahm 1995; Desmond and Savidge 1996, 1998, 1999; Sidle et al. 1998). Burrowing Owls are semicolonial (Bent 1961, Haug et al. 1993), and often use black-tailed prairie dog or Richardson's ground squirrel colonies as nest sites (Bent 1961, Grant 1965, Berdan and Linder 1973, Butts 1973, Konrad and Gilmer 1984, MacCracken et al. 1984, Ratcliff 1986, Thompson and Anderson 1988, Desmond 1991, Plumpton and Lutz 1993, Desmond et al. 1995, Desmond and Savidge 1996, Toombs 1997). Burrow availability may be limiting in areas lacking colonial burrowing rodents (Desmond and Savidge 1996); in these areas, Burrowing Owls frequently use American badger (Taxidea taxus) excavations as nest sites (Scott 1940, James and Seabloom 1968, Butts 1973, Stewart 1975, Gleason 1978, Konrad and Gilmer 1984, Gleason and Johnson 1985, Rich 1986, Haug and Oliphant 1990, Desmond and Savidge 1996). Burrowing Owls also nest less commonly in the burrows of Douglas' squirrels (Tamiasciurus douglasii), white-tailed 
prairie dogs (Cynomys leucurus), Gunnison’s prairie dogs (Cynomys gunnisoni), yellow-bellied marmots (Marmota flaviventris), woodchucks (Marmota monax), striped skunks (Mephitis), foxes (red and kit foxes [Vulpes spp.] or gray foxes [Urocyon cinereoargenteus]), gray wolves (Canis lupus), coyotes (Canis latrans), and nine-banded armadillos (Dasypus novemcinctus) (Stoner 1932, Bent 1961, Grant 1963, Martin 1973, Clark et al. 1982, Martin 1983, Gleason and Johnson 1985, Rich 1986, Green and Anthony 1989). Where mammal burrows are scarce, Burrowing Owls have been found nesting in natural cavities in rocks (Gleason 1978, Gleason and Johnson 1985, Rich 1986).

Burrows used as nest sites in northcentral Colorado were closer to roads, farther from perches, and surrounded by more bare ground and by shorter grasses and forbs than non-nest burrows (Plumpton and Lutz 1993). In southcentral Saskatchewan, Burrowing Owls avoided nesting in areas of woody vegetation, tilled ground, and tame pastures (Wedgwood 1976). However, another study in southcentral Saskatchewan found that owls nesting in tame pasture had a higher rate of nesting success than those nesting in native pasture, possibly due to lower depredation rates or greater prey availability in tame pasture than in native pasture (Haug 1985). Burrowing Owls in northcentral Oregon occupied 100\% (actual number not given) of the available American badger excavations in areas dominated by snakeweed (Gutierrezia sarothrae) (Green and Anthony 1989). (In this document, the term 'occupied' refers to nest sites that are inhabited by Burrowing Owls). Owl nests also were found in open areas of short vegetation dominated by antelope bitterbrush (Purshia tridentata) or downy brome (Bromus tectorum). In an agricultural area of southeastern Idaho, seven of nine nests were adjacent to alfalfa (Medicago sativa) fields; locations of the remaining two nests were not given (Gleason 1978). Nests near edges of agricultural fields may provide high insect populations and close proximity to foraging areas (Butts 1973, Rich 1986). Also in southeastern Idaho, owls nested in yellow-bellied marmot burrows or natural cavities (called outcrop sites) more often than in American badger excavations (Rich 1984, 1986). Small outcrops were preferred over larger outcrops, and owl sites had southerly aspects more frequently than did randomly chosen sites. Cover of downy brome within $50 \mathrm{~m}$ of the burrow was higher at nest sites than at non-nest sites, and bare ground and rock cover were high around nest sites.

Burrowing Owls appear to prefer black-tailed over white-tailed prairie dog colonies, presumably because habitat is more open and vegetation is shorter around black-tailed prairie dog colonies than around white-tailed prairie dog colonies (Martin 1983). In the Platte River Valley of Nebraska, Burrowing Owl nests were found only in upland prairie, and often were associated with black-tailed prairie dog colonies (Faanes and Lingle 1995). Of 92 Burrowing Owl nests in western Nebraska, 85\% occurred in black-tailed prairie dog colonies, and 15\% in American badger excavations (Desmond 1991). Of 543 Burrowing Owl nests in the Oklahoma Panhandle, 66\% occurred in black-tailed prairie dog colonies, although colonies composed $<20 \%$ of the landscape surveyed (Butts 1973, Butts and Lewis 1982). Five nests were in wheat fields and edges of fallow fields where vegetation was kept short by black-tailed prairie dogs, and one nest was found in a sand sagebrush (Artemisia filifolia)/grass pasture. All nests were found in vegetation $\leq 10 \mathrm{~cm}$ tall. In eastern Wyoming, nests were located in colonies of either black-tailed or white-tailed prairie dogs (Thompson 1984, Thompson and Anderson 1988). Burrowing Owls in central Wyoming selected burrows surrounded by early-successional plant communities (Thompson 1984). In southwestern South Dakota, Burrowing Owls used abandoned black-tailed prairie dog burrows surrounded by a high percentage of bare ground, low 
shrub coverage, and shorter vegetation than that in the rest of the colony (MacCracken et al. $1985 a$ ).

Burrowing Owls sometimes concentrate their nests at the edges of prairie dog colonies (Butts 1973, Desmond et al. 1995, Toombs 1997). Reasons for this are unknown, but birds nesting near edges of prairie dog colonies may benefit from increased perch availability, high insect populations, and close proximity to foraging areas (Butts 1973, Rich 1986).

Burrowing Owls have been found in active prairie dog colonies (Butts 1973; Desmond and Savidge 1996, 1998; Toombs 1997) (in this document, the term 'active' refers to prairie dog colonies or burrows that are in use by prairie dogs), and in relatively inactive prairie dog colonies (Bent 1961, MacCracken et al. 1984). However, owls in larger, well-populated prairie dog colonies are more likely to return to nesting sites, experience lower rates of nest depredation, and have higher rates of nesting success than owls in smaller colonies or in colonies with lower densities of prairie dogs (Butts 1973; Desmond and Savidge 1996, 1998, 1999; Toombs 1997). Removal of prairie dogs from colonies is followed by rapid deterioration of burrows and encroachment of dense vegetation; owls eventually stop breeding at sites from which prairie dogs have been eliminated (Grant 1965, Butts 1973). Black-tailed prairie dog colonies in Oklahoma became unsuitable for Burrowing Owls within 1-3 yr after abandonment by prairie dogs due to the encroachment of dense vegetation (Butts 1973). Additionally, burrows may require structural maintenance by prairie dogs to remain suitable for owls (MacCracken et al. 1985a, Desmond 1991, Desmond and Savidge 1999). All nesting attempts in northcentral Colorado occurred in active black-tailed prairie dog colonies (Pezzolesi 1994). Black-tailed prairie dog colonies used by owls contained higher densities of burrows than black-tailed prairie dog colonies that contained no owl nests (Plumpton 1992, Plumpton and Lutz 1993). In southeastern Colorado, prairie dog colonies that were occupied by owls had higher means for total burrow density (101 burrows/ha in occupied colonies, vs. 76 burrows/ha in unoccupied colonies), active burrow density (46 burrows/ha vs. 27 burrows/ha), and percent active burrows (43\% vs. 24\%) than unoccupied colonies (Toombs 1997). The density of Burrowing Owls in prairie dog colonies in northeastern Colorado was positively related to the percentage of active burrows (Hughes 1993). At least 50\% of the burrows were active in 26 of 27 occupied colonies. For prairie dog colonies with over $90 \%$ active burrows, mean density of Burrowing Owls was 2.85 owls/ha, and for those with $70-80 \%$ active burrows, mean density was 0.57 owls/ha, suggesting that owls selected colonies with a high proportion of active burrows. In Nebraska, Burrowing Owl density in black-tailed prairie dog colonies was negatively correlated with the density of inactive burrows (Desmond 1991) and positively correlated with density of active burrows (Desmond et al. 2000).

Adult and young Burrowing Owls may use several non-nest (satellite) burrows, possibly to avoid nest parasites (Grant 1965; Butts 1973; Butts and Lewis 1982; Konrad and Gilmer 1984; Haug 1985; Desmond 1991; Plumpton and Lutz 1993; Desmond and Savidge 1999). Use of satellite burrows also may be a predator avoidance strategy; spreading the brood among several burrows may increase the chances that $\geq 1$ chick escapes depredation (Desmond 1991, Desmond et al. 1997, Toombs 1997, Desmond and Savidge 1999). In central Saskatchewan, an average of six available burrows occurred within $30 \mathrm{~m}$ of the nest burrow (Haug 1985; Haug and Oliphant 1987, 1990). Of five nest burrows in western North Dakota, average distance from the four nearest non-nest burrows was $7.8 \mathrm{~m}$ (Stockrahm 1995). Burrowing Owl chicks in western Nebraska selected satellite burrows that were active more than expected by chance, possibly 
because active burrows were better maintained than inactive burrows (Desmond and Savidge 1999). Successful nests had more active burrows within $75 \mathrm{~m}$ of the nest burrow than unsuccessful nests. Observations made at 15 burrow sites by James and Seabloom (1968) revealed that most family units in southwestern North Dakota used from one to three satellite burrows, although a few family units used from two to ten satellite burrows. In eastern Wyoming, most (actual number not given) nesting areas contained between two and 11 available burrows (Thompson 1984). Three Burrowing Owl families in Iowa used from one to five satellite burrows (Scott 1940). In Oklahoma, black-tailed prairie dog colonies appeared to be the only habitat with a sufficient density of burrows to provide satellite burrows for owls (Butts and Lewis 1982).

Burrowing Owls in northcentral Oregon appeared to require observation perches in habitats where the vegetation was $>5 \mathrm{~cm}$ tall (Green and Anthony 1989). Owls did not nest in habitats dominated by rabbitbrush (Chrysothamnus nauseosus) or bunchgrasses, probably due to a combination of tall $(>20 \mathrm{~cm})$ vegetation and a lack of perches. In Minnesota, territories always included observation perches such as fence posts, dirt mounds, boulders, or utility poles (Grant 1965). Studies in northcentral Oregon and northcentral Colorado, where vegetation was short ( $<4.7 \mathrm{~cm}$ and $<8 \mathrm{~cm}$, respectively), found that observation perches were not used (Green and Anthony 1989) or were farther from nests than expected by chance (Plumpton and Lutz 1991, Plumpton 1992).

In northcentral Oregon, soil texture affected the longevity and re-occupation rates of American badger excavations by Burrowing Owls (Green and Anthony 1989) (in this document, the term 're-occupy' refers to the repeated use across years of specific burrows or excavations by Burrowing Owl populations, and the term 're-use' refers to the repeated use across years of generalized nesting areas by Burrowing Owl populations; burrow fidelity is the re-occupation across years of specific burrows or excavations by the same owl or breeding pair). Of 85 nests in loamy sand soils, $46 \%$ were silted in within $1 \mathrm{yr}$, and $52 \%$ of the remaining excavations were re-occupied. Of 13 nests in silty loam soils, none were silted in within $1 \mathrm{yr}$, and all were reoccupied. Black-tailed prairie dog colonies, and thus owl nests, were not placed on sandy soils in southeastern Colorado; black-tailed prairie dogs may find sand an unsuitable substrate for maintaining stable burrows (Toombs 1997). Ideal Burrowing Owl nesting habitat in Saskatchewan appeared to occur in high quality lacustrine (ancient lake-bottom) soils, which also contained the most fragmented habitats due to intensive agricultural development (Wellicome and Haug 1995; Warnock and James 1997; T. I. Wellicome, pers. comm.). Consequently, Burrowing Owls in Saskatchewan frequently use poor soils, although this does not indicate a preference for poor soils (Wedgwood 1976; T. I. Wellicome, pers. comm.). In southwestern South Dakota, soils at nest sites were silty clay loams (MacCracken et al. 1985a). Burrowing Owls in eastcentral Wyoming nested on sites with sandy loam soils (Thompson 1984). A table near the end of the account lists the specific habitat characteristics for Burrowing Owls by study.

\section{Prey habitat:}

Burrowing Owls prey primarily on arthropods and small mammals (Butts 1973, Gleason 1978, MacCracken et al. 1985b), and are believed to be opportunistic feeders (Tyler 1983, Thompson and Anderson 1988, John and Romanow 1993). In northcentral Colorado, the consumption of arthropods with respect to their abundance was disproportionate (Plumpton 
1992, Plumpton and Lutz 1993). In southeastern Alberta, the consumption of meadow voles (Microtus) and deer mice (Peromyscus) was highly disproportionate to their abundance (Schmutz et al. 1991).

Prey abundance affects reproductive success of Burrowing Owls (Gleason 1978, Wellicome 1994, Clayton 1997, Wellicome et al. 1997, Poulin et al. 1998). Prey abundance appeared to be limiting during the nestling stage in Saskatchewan (Wellicome 1994, 1997a; Wellicome et al. 1997). Owls receiving supplementary food during the nestling stage produced $41 \%$ more fledglings than owls receiving no supplementary food (Wellicome et al. 1997), and the incidence of cannibalism was lower at food-supplemented than at unsupplemented nests (Wellicome 1997a). Additionally, fledglings from food-supplemented nests were heavier than those from unsupplemented nests (Wellicome 1994). Enhanced reproductive output during a single year in southeastern Saskatchewan was attributed to a superabundance of voles during the breeding season (Clayton 1997, Wellicome 1997a, Todd 1998), as was a significant increase in the population of breeding pairs the following season (Poulin et al. 1998). In southeastern Idaho, starvation of fledgling and dispersing owls appeared to be an important mortality factor (Gleason 1978).

Burrowing Owls forage in a variety of habitats, including cropland, pasture, prairie dog colonies, fallow fields, and sparsely vegetated areas (Butts and Lewis 1982, Thompson and Anderson 1988, Desmond 1991, Haug et al. 1993, Wellicome 1994). In southeastern Saskatchewan, prey abundance and species richness were evaluated in native grassland, road rights-of-way, cropland, summer fallow, pasture, and hayland (Wellicome 1994). Habitats that were associated with periodic plowing (cropland and fallow fields) had a lower prey-species richness than did native grassland, road rights-of-way, pasture, or hayland. Habitats with tall (30-60 cm) vegetative cover (road rights-of-way, native grassland, and mature cropland) had more abundant prey than hayland, pasture, or fallow fields (Wellicome 1994, Wellicome and Haug 1995). However, vegetation $>1 \mathrm{~m}$ tall may be too tall for Burrowing Owls to locate or catch prey; for example, although prey abundance in cropland was high in southern Saskatchewan, Burrowing Owls avoided cropland as foraging habitat (Haug and Oliphant 1987, 1990; Wellicome 1994). Owls in central Saskatchewan appeared to prefer grass/forb areas (e.g., road rights-of-way and uncultivated areas) over non-irrigated cropland or native pastures, possibly because grasshopper (Acrididae) abundances were high in the preferred areas (Haug 1985, Haug and Oliphant 1990). In southeastern Idaho, the occurrence of Great Basin pocket mice (Perognathus parvus) and American burying beetles (Nicrophorus americanus) was positively correlated with downy brome, whereas the abundance of montane voles (Microtus montanus) was positively correlated with farmland (Rich 1986). In the Oklahoma Panhandle, black-tailed prairie dog colonies that were densely populated with owls were located near more cropland and less grassland than less densely populated colonies, possibly because of higher rodent and arthropod populations in cropland (Butts 1973). However, black-tailed prairie dog colonies provided almost half of the owl's mid-summer prey (Butts and Lewis 1982). In western Nebraska, Burrowing Owls nesting in black-tailed prairie dog colonies took foraging trips of longer duration than owls nesting in American badger excavations within pastures, suggesting that prey was more limiting to owls nesting in prairie dog colonies than to owls nesting in American badger excavations (Desmond 1991). Increased competition for prey may explain the difference in duration of foraging trips; Burrowing Owls nested at higher densities in the prairie dog colonies. Burrowing Owls in Idaho foraged in irrigated crop fields where voles were 
plentiful (Rich 1986). In southeastern Alberta, abundances of grasshoppers and deer mice (Peromyscus maniculatus) were negatively correlated with vegetation height and density, and vole abundance was positively correlated with vegetation height and density (Clayton 1997). Burrowing Owls in southeastern Alberta preyed on grasshoppers, deer mice, and voles, but consumed 1.45 voles for every mouse consumed in spite of a 113:6 ratio of mice to voles trapped (Schmutz et al. 1991). Wheat fields in Canada contained a low diversity of small mammals, and were dominated by deer mice, which had low abundances early in the breeding season, although they attained very high abundances later in the breeding season (Wellicome and Haug 1995). Heavily grazed pasture had a very low relative abundance of prey; thus heavy grazing in their foraging areas may be detrimental to Burrowing Owls.

\section{Area requirements:}

Burrowing Owls generally stay close to the nest burrow during the daylight hours, and forage farther from the nest between dusk and dawn (Haug 1985, Haug and Oliphant 1990). Thus, nesting-area requirements can be inferred from diurnal activity, and foraging-area requirements can be inferred from nocturnal activity (T. I. Wellicome, pers. comm.). Nestingarea territory for two pairs in Minnesota was 4.8 and 6.4 ha, and 4-6 ha for five to eight pairs in North Dakota (Grant 1965). Average diurnal foraging area of owls in eastern Wyoming encompassed 3.5 ha (number of foraging areas not given) (Thompson 1984).

Mean nearest-neighbor distances in northcentral Oregon differed between successful and deserted owl nests (Green and Anthony 1989). For two pairs of nests with inter-nest distances $<60 \mathrm{~m}$, both nests were abandoned. For nine pairs of owl nests with inter-nest distances from 60 to $110 \mathrm{~m}$, at least one of the two nests was abandoned. Yet only $14 \%$ of 21 pairs of owl nests with inter-nest distances $>110 \mathrm{~m}$ abandoned at least one of the two nests. Such abandonments were attributed to competition for food resources. In northcentral Colorado, mean inter-nest distances for eight Burrowing Owls nesting in black-tailed prairie dog colonies was $101 \mathrm{~m}$ (Plumpton 1992). Mean nearest-neighbor distance for owls nesting in 20 American badger excavations in western Nebraska was $240 \mathrm{~m}$, compared to mean nearest-neighbor distances of $105 \mathrm{~m}$ for 118 non-clustered nests in small prairie dog colonies and $125 \mathrm{~m}$ for 105 nest clusters in large prairie dog colonies (Desmond 1991, Desmond et al. 1995, Desmond and Savidge 1996). Available excavations may be limiting to owls nesting outside of prairie dog colonies.

Within prairie dog colonies, Burrowing Owls have been observed to aggregate their nests into clusters (Butts 1973; Desmond 1991; Desmond et al. 1995, 2000; Desmond and Savidge 1996). Clustered nest distributions may reduce depredation risks by allowing owls to alert one another to potential predators. In western Nebraska, Burrowing Owls in larger (>35 ha) blacktailed prairie dog colonies nested in clusters with mean nearest-neighbor distances of $125 \mathrm{~m}$, whereas owls in smaller ( $<35 \mathrm{ha}$ ) colonies nested with random distributions and with mean nearest-neighbor distances of $105 \mathrm{~m}$, suggesting that space requirements may limit owls in smaller black-tailed prairie dog colonies (Desmond 1991, Desmond et al. 1995, Desmond and Savidge 1996). Mean densities of owls within 21 Burrowing Owl clusters in large prairie dog colonies ranged from 1.2 to 1.3 owls/ha; mean densities of owls in 26 small prairie dog colonies ranged from 1.7 to 5.8 owls/ha, and mean densities of owls within 15 large prairie dog colonies ranged from 0.2 to 0.17 owls/ha.

In northeastern Colorado, 27 prairie dog colonies used by owls ranged in size from 1.9 to 167.6 ha (Hughes 1993). Density of Burrowing Owls was negatively related to colony size. The 
size of prairie dog colonies in western Nebraska was positively correlated with fledging success rates (Desmond 1991). In Saskatchewan, no significant relationships were detected between pasture size and proportion of failed nests, number of chicks produced per successful nest, adult or juvenile survivorship, or movement of owls between pastures of various sizes (James 1993).

Foraging-area requirements are considerably larger than nesting-area requirements; in southern Saskatchewan, six radio-tagged male owls foraged within areas ranging from 14 to 481 ha (mean of 241 ha) (Haug 1985, Haug and Oliphant 1990). Four owls in a heavily cultivated region of southern Saskatchewan had foraging areas averaging 35 ha (Sissons et al. 1998). Researchers noted the extreme disparity between the reported foraging-area means in southern Saskatchewan, but offered no explanation. Data for the latter study were gathered during the same year that southeastern Saskatchewan experienced the superabundance of voles noted above. Foraging areas in central Saskatchewan appeared to increase with decreasing prey densities (Haug 1985).

Habitat fragmentation may allow predators to find nests easily (James et al. 1997, Warnock and James 1997). In Saskatchewan, crowding of owls into smaller habitat patches may increase nest abandonment through events such as depredation (both intra- and inter-specific), foraging interference, and aggression (Warnock and James 1997). Additionally, extirpation of owls from habitat patches was less probable with increasing habitat continuity (Warnock 1996, 1997). Pastures occupied by owls had a lower edge-to-area ratio than randomly chosen, unoccupied pastures (Wellicome and Haug 1995; Warnock 1996, 1997). Burrowing Owls in southeastern Alberta did not appear to be limited by habitat availability (Schmutz and Moody 1989; Schmutz 1993, 1997). In an agriculturally fragmented area of northeastern Colorado, owls nested in black-tailed prairie dog colonies around which shortgrass patches were more numerous than cropland patches, but due to small size, shortgrass patches composed a smaller percentage of the landscape than crop patches by area (Biddle 1996). On average, shortgrass patches were closer to the perimeter of black-tailed prairie dog colonies than other patch types.

Brown-headed Cowbird brood parasitism:

No known records of brood parasitism by Brown-headed Cowbirds (Molothrus ater) exist.

Breeding-season phenology and site fidelity:

Burrowing Owls occupy their breeding grounds within the Great Plains from about early April until September (Bent 1961, Grant 1965, Maher 1974, Wedgwood 1976, Gleason 1978, Haug 1985, Ratcliff 1986, Haug and Oliphant 1990, De Smet 1992). In the southern Great Plains, some owls overwinter on the breeding grounds (Butts 1973, Arrowood et al. 1998). Renesting attempts following failed nests have been reported in western Oklahoma (Butts 1973), western Nebraska (Desmond 1991), and Saskatchewan (Wedgwood 1976, Haug 1985).

Burrow fidelity has been reported in some areas (Schmutz et al. 1989, Feeney 1997). More frequently, Burrowing Owls reuse traditional nesting areas without necessarily using the same burrow (Wedgwood 1976, Gleason 1978, Otnes 1980, Rich 1984, Plumpton 1992, Haug et al. 1993, Pezzolesi 1994, De Smet 1997, Plumpton and Lutz 1998, Clayton and Schmutz 1999, Lutz and Plumpton 1999). Burrow fidelity and nest area re-use may be enhanced if birds are reproductively successful during the previous year (Pezzolesi 1994, De Smet 1997, Feeney 1997, Plumpton and Lutz 1998). For adult males that returned to former nest sites in Colorado, 
productivity during the previous year was not significantly higher than productivity of males that changed nest sites (Lutz and Plumpton 1999). Conversely, productivity was higher in the preceding year for female owls that returned to former nest sites than for females that changed nest sites in following years. Return rates for adult males and females were not significantly different. Owls reused traditional nesting areas in western Nebraska despite drastic betweenseason declines in habitat quality (Desmond and Savidge 1998, Desmond et al. 2000). In southeastern Idaho, burrows were re-occupied (though not necessarily by the same owls) for 1-3 yr, and then vacated for a period before being re-occupied (Rich 1984). Burrow re-occupation was higher in rock outcrop sites (58\% of 113 burrows re-occupied) than in American badger excavation sites (31\% of 159 excavations re-occupied), possibly due to the more durable nature of the former. Of 113 outcrop sites, no burrows were destroyed during the course of the 7-yr study; of 159 American badger excavations, 16\% were destroyed. Also in Idaho, 60\% of 15 American badger excavations were re-occupied the following year (Gleason 1978). Of 20 blacktailed prairie dog colonies in northcentral Colorado, 90\% were reused the following year (Plumpton and Lutz 1993). Of 31 owls, 39\% returned to the study area during the second year of the study, and 25\% used a burrow within the same colony that they had used previously. In Saskatchewan, sites exhibiting owl re-use were less isolated, and had more owl-occupied sites nearby ('nearby' was not defined) than sites that were not reused (Warnock and James 1996). In Manitoba, 38\% of 118 territories were reoccupied (De Smet 1992). Owls nested 0-45 km from their natal site. Of 417 young and 54 adults banded, 18\% and 19\% returned, respectively.

\section{Species' response to management:}

Urban development (Zarn 1974, Konrad and Gilmer 1984, Barclay et al. 1998), conversion of pastures to cropland (Grant 1965, Konrad and Gilmer 1984, Ratcliff 1986), and cultivation of grasslands (Grant 1965, Faanes and Lingle 1995) limit Burrowing Owl populations through the destruction of nesting habitat. The extirpation of gray wolves and increased tree cover on the prairie have allowed populations of other mammalian and avian predators to increase, probably to the detriment of Burrowing Owl populations (Wellicome and Haug 1995).

Elimination of burrowing rodents through control programs has been identified as the primary factor in the recent and historical decline of Burrowing Owl populations (Grant 1965; Butts 1973; Zarn 1974; Butts and Lewis 1982; Evans 1982; Ratcliff 1986; Pezzolesi 1994; Faanes and Lingle 1995; Desmond and Savidge 1996, 1998, 1999; Toombs 1997; Barclay et al. 1998; Murphy et al. 2001). In particular, preservation of black-tailed prairie dogs and Richardson's ground squirrels may be essential to the conservation of Burrowing Owls. Populations of black-tailed prairie dogs are in danger of local extirpation, and their colonies have become so isolated through fragmentation that re-population through natural dispersal and colonization is unlikely (Benedict et al. 1996). Fragmentation and isolation of habitat patches are potentially important factors in the decline of black-tailed prairie dog populations, but are largely unstudied. Declines of Burrowing Owl populations north and east of the Missouri River in North Dakota may be related to declines in Richardson's ground squirrel populations (Murphy et al. 2001). South and west of the Missouri River, Burrowing Owl population declines may be related to reductions in populations of black-tailed prairie dogs. In western Nebraska, a 63\% decline in Burrowing Owl numbers over a 7-yr period in 17 black-tailed prairie dog colonies was associated with declines in black-tailed prairie dog densities due to prairie dog control activities (Desmond and Savidge 1998, Desmond et al. 2000). Burrowing Owl reproductive success was 
positively correlated, and nest depredation by American badgers was negatively correlated with the density of active black-tailed prairie dog burrows. Whereas nesting success for owls nesting in American badger excavations was comparable with findings from other areas (58\%, with three fledglings per nest), lower-than-average nesting success in black-tailed prairie dog burrows (48\%, with 1.9 fledglings per nest) appeared to be related to prairie dog control efforts (M. J. Desmond and J. A. Savidge, University of Nebraska, Lincoln, Nebraska, unpublished data).

Burrowing Owls use shredded horse or cow manure to line their nests (Scott 1940, Salt and Wilk 1958, Martin 1973, Green and Anthony 1989, Desmond et al. 1997), possibly to mask nest odors as a predator-avoidance strategy (Martin 1973, Green and Anthony 1989, Desmond et al. 1997). If fresh manure is not available for owls, it may be necessary to import and provide it (Green and Anthony 1997). In northcentral Oregon, 72\% of 32 successful nests were lined with manure, whereas only $13 \%$ of 15 depredated nests were lined with manure.

Little information exists on the response of Burrowing Owls to burning. In northcentral Oregon, Burrowing Owls were observed nesting in American badger excavations in previously unused areas that recently had been burned, suggesting that fire may create suitable habitat by reducing vegetation around potential nest sites (Green and Anthony 1989). Additionally, in northwestern North Dakota, postsettlement fire suppression may be responsible for the development of a taller, denser, and woodier plant community than previously existed (Murphy 1993). These vegetational shifts may have been responsible for the local extirpation of Burrowing Owls.

In northcentral Colorado, mowing may be used to control growth of grasses and woody vegetation in areas where black-tailed prairie dogs have been eliminated; abandoned black-tailed prairie dog colonies that were not mowed were not used by owls (Plumpton 1992). Mowing also may enhance the attractiveness of nest sites for Burrowing Owls returning from the wintering grounds (Plumpton and Lutz 1993). Mowing throughout the breeding season apparently does not adversely affect nesting Burrowing Owls (T. I. Wellicome, pers. comm.). However, burrows may require maintenance by prairie dogs in order to ensure their long-term suitability for owls; it may be necessary to release prairie dogs into inactive colonies (MacCracken et al. 1985a; T. I. Wellicome, pers. comm.).

Burrowing Owls prefer grasslands grazed heavily by cattle or prairie dogs (James and Seabloom 1968, Butts 1973, Wedgwood 1976, MacCracken et al. 1985a, Bock et al. 1993). Cessation of grazing negatively impacts Burrowing Owl populations (T. I. Wellicome, pers. comm.). In southcentral Saskatchewan, heavily grazed, poor soils were used frequently by Burrowing Owls, and moderate to heavy grazing on good soils reduced lush vegetative growth and provided suitable habitat (Wedgwood 1976). Owls in Saskatchewan and Alberta nested in pastures with shorter vegetation than occurred in randomly chosen pastures, and preferred native or tame pastures over cultivated land (Clayton 1997). In the Oklahoma Panhandle, grazing of taller grasses may attract ground squirrels and prairie dogs, thus increasing burrow availability (Butts 1973). Burrowing Owls in North Dakota nested in moderately or heavily grazed mixedgrass pastures, but not in hayed or lightly grazed mixed-grass (Kantrud 1981). Declines in Burrowing Owl populations north and east of the Missouri River in North Dakota may be due to a reduction over the past $20 \mathrm{yr}$ in the amount of sheep grazing that occurs in the region (Murphy et al. 2001). Researchers rarely noticed native prairie that was cropped short by grazing. In the Platte River Valley of Nebraska, preferred nest sites were in heavily grazed or mowed native grasslands (Faanes and Lingle 1995). Optimal breeding habitat in portions of Colorado, 
Montana, Nebraska, North Dakota, South Dakota, and Wyoming occurred in heavily grazed areas with aridic ustoll soils and grazed areas with typic boroll soils (Kantrud and Kologiski 1982).

Cultivation and fragmentation of grassland habitat in Canada have allowed populations of predators that prey on Burrowing Owl to increase (Wellicome and Haug 1995). Burrowing Owls near Hanna, Alberta, where $85 \%$ of original grassland remained uncultivated, experienced the lowest depredation rates ( $<5 \%$ of nests [sample size not given]) of any study area in Canada. However, in western Nebraska, Burrowing Owls that nested in landscapes dominated by cropland experienced higher fledging success (mean of 3.23 fledglings/pair) than owls nesting in rangeland landscapes (mean of 1.49 fledglings/pair), and the difference appeared to be related to depredation rates (Desmond 1991). Precipitation during the year of this finding was slightly above normal, but during a drought year, no difference in the fledging success was observed between the areas.

Use of insecticides and rodenticides in Burrowing Owl habitat can be especially detrimental; pesticides not only reduce the owl's food supply and the number of burrowing mammals, but these chemicals also may be toxic to the owl (Ratcliff 1986, James and Fox 1987, James et al. 1990, Baril 1993, Berkey et al. 1993, PMRA 1995, Hjertaas 1997a, Wellicome 1997b). Burrowing Owls have been noted to ingest poisoned rodents and to forage on the ground for insects in areas littered with poison grains (Butts 1973, James et al. 1990). In southern Saskatchewan, owls in pastures treated with strychnine-coated grain weighed less than owls in control pastures, suggesting a sublethal effect or a reduction in small-rodent prey (James et al. 1990). A breeding population in the Oklahoma Panhandle declined by $71 \%$ within $1 \mathrm{yr}$ after sodium fluoroacetate was applied to the prairie dog colony in which the owls were nesting (Butts 1973). By the end of the breeding season, no owls remained at the site. Owl burrows occasionally are fumigated and sealed in the course of rodent-control programs (Butts 1973).

Carbaryl and carbofuran are two insecticides used to control agricultural pests (PMRA 1995). In Saskatchewan, reproductive output of Burrowing Owls was not diminished significantly by one or more exposures to carbaryl within 50 or $400 \mathrm{~m}$ of the nest burrow; however, spraying of carbofuran within $50 \mathrm{~m}$ of the nest burrow caused a $54 \%$ reduction in the number of young per nest (James and Fox 1987). When both carbaryl and carbofuran were sprayed within $400 \mathrm{~m}$ of the nest, productivity of pairs decreased about 35\% more than when carbaryl alone was applied. Direct overspray of carbofuran to the nest burrow resulted in an $83 \%$ reduction in brood size and an $82 \%$ reduction in nesting success (James and Fox 1987, Fox et al. 1989). Carbofuran application within $50 \mathrm{~m}$ of the nest burrow, without direct overspray, resulted in a $17 \%$ reduction in brood size and a $27 \%$ reduction in nesting success compared with burrows exposed to carbaryl or chloropyrifos. Carbofuran has been banned in all of its granular formulations in the United States and Canada (PMRA 1995; L. Cole, Environmental Protection Agency, Office of Pesticide Programs, Washington, D. C., pers. comm.; P. Mineau, Canadian Wildlife Service, Hull, Québec, pers. comm.), as well as in most of its liquid formulations in Canada (PMRA 1995); however, it is still certified for use in corn fields in Canada, and pesticide drift could affect Burrowing Owls nesting near such fields (P. Mineau, pers. comm.). Additionally, liquid carbofuran is still registered for several uses in the United States; of particular danger to the Burrowing Owl are uses of this chemical in corn and alfalfa fields (L. Cole, pers. comm.; P. Mineau, pers. comm.). 


\section{Management Recommendations:}

Educate the public, especially private landowners, about the status of Burrowing Owls, the benefits of protecting habitat for the species and for burrowing mammals, and the negative effects of insecticides (Butts 1973; James and Fox 1987; Thomson 1988; Hjertaas 1993; M. J. Desmond, Texas A\&M University, Kingsville, Texas, pers. comm.). Develop an educational program for schools and for outdoor education, and include the media in these activities (Thomson 1988). Work to improve the image of prairie dogs (Benedict et al. 1996).

Enlist landowners' help in protecting burrows. Operation Burrowing Owl (a private stewardship program in Canada) has been extremely successful at obtaining landowner cooperation in conservation efforts, and has provided valuable population trend data for Canadian owls (Hjertaas 1997b).

Enlist municipal, state, or federal governments in obtaining easements or purchasing land in prime owl habitat (Butts 1973, Haug and Oliphant 1987, Thomson 1988, Toombs 1997). Offer financial incentives to landowners who avoid agricultural activities that negatively affect the Burrowing Owl (Warnock 1996, Thomson 1988).

Encourage municipal governments and agricultural representatives to reduce or restrict the use of pesticides, and to use pesticides of low toxicity to nontarget species (Thomson 1988).

In the United States, government agencies should shift from subsidizing prairie dog reduction to leadership in finding workable alternatives that maintain viable prairie dog communities and ranching systems (Benedict et al. 1996; Desmond and Savidge 1999). Recognize that the eradication of prairie dogs may be economically costly, agriculturally unnecessary, and ecologically detrimental (Benedict et al. 1996).

In Saskatchewan, identify owl nesting sites on public lands so that they can be protected; most known owl sites occur on privately owned land (Warnock and James 1997).

Preserve traditional nesting sites (Butts 1973, Zarn 1974, Haug 1985, Ratcliff 1986, Warnock 1997). Burrowing Owls often reuse nesting sites occupied in previous years (Butts 1973; Rich 1984; Haug 1985; Haug and Oliphant 1990; Plumpton 1992; Plumpton and Lutz 1993; Toombs 1997; M. J. Desmond and J. A. Savidge, unpublished data).

Maintain large, contiguous areas of native grassland (Benedict et al. 1996; Warnock 1997; Warnock and James 1997; R. K. Murphy, U.S. Fish and Wildlife Service, Kenmare, North Dakota, pers. comm.), including areas of treeless plains (Clayton and Schmutz 1999).

Create a patchwork of reserves with sustainable land uses in surrounding buffer areas (Clayton and Schmutz 1999). Because owls forage over tall grass and nest and roost in short grass, a mosaic of habitats may be important in conserving habitat. 
Provide fresh horse or cow manure near nesting areas if none is available (Green and Anthony 1997). Burrowing Owls use shredded manure to line their nests (Scott 1940, Salt and Wilk 1958, Martin 1973, Green and Anthony 1989, Desmond et al. 1997), possibly to mask nest odors as a predator-avoidance strategy (Martin 1973, Green and Anthony 1989, Desmond et al. 1997). In northcentral Oregon, $72 \%$ of 32 successful nests were lined with manure, whereas only $13 \%$ of 15 depredated nests were lined with manure.

Install artificial nest structures where natural burrows are scarce (Haug 1985, Thomson 1988). During 2 yr in Saskatchewan, 5\% of 63 nests in artificial nest structures were depredated, whereas 37\% of 35 nests in natural burrows were depredated (Wellicome et al. 1997).

Provide supplemental food during the nestling stage as a short-term solution if food seems limiting (Wellicome 1994, 1997a; James et al. 1997); take care not to overfeed as excessive food caching may attract predators (Delevoryas 1997).

Provide observation perches where vegetation is tall (Green and Anthony 1997). In Oregon, Burrowing Owls appeared to require observation perches where vegetation heights were $>5 \mathrm{~cm}$. However, in Colorado, observation perches were farther from nest burrows than expected by chance where vegetation was $<8 \mathrm{~cm}$ tall (Plumpton and Lutz 1991, Plumpton 1992). In Minnesota, territories always included observation perches (Grant 1965).

Allow heavy grazing on saline, gravelly, stony, or sandy areas, because these areas are used frequently by Burrowing Owls in Saskatchewan (Wedgwood 1976). Allow moderate to intense grazing on good soils that otherwise would support tall vegetation.

Transplant owls from other nearby populations to areas where Burrowing Owl populations are low, but where suitable habitat exists (open, grazed grassland with natural burrows, low predator density, sufficient area, and adequate prey base), such as southwestern Manitoba.

Transplantation attempts should be considered experimental until improved methods are devised (Thomson 1988; M. J. Desmond, pers. comm.). A Burrowing Owl reintroduction program in British Columbia indicated that 1-yr-old, captive-bred Burrowing Owls were capable of raising broods after being released, migrating south in winter, and returning to release sites the following spring (Low and Leupin 1998). However, a 4-yr release program in Minnesota involving 104 banded juvenile Burrowing Owls that had been captured in South Dakota resulted in no reported sightings of the released birds. Furthermore, there were no reports of successful nesting by Burrowing Owls in Minnesota in the 8 yr following the release (Martell et al. 1998).

If insect control is necessary, choose insecticides with the lowest toxicity to nontarget organisms (James and Fox 1987, Fox et al. 1989).

Do not spray pesticides within 400-600 m of owl nest burrows during the breeding season (Haug 1985; Haug and Oliphant 1987, 1990; James and Fox 1987).

Regulate poisoning and shooting of prairie dogs, particularly on public lands (Benedict et al. 1996, Toombs 1997). 
If lethal control of burrowing mammals is necessary, restrict the timing of control activities to avoid the period when Burrowing Owls choose nest sites or are nesting (Butts 1973). For example, in Oklahoma, restrict poisoning to January and February. Consider relocating owls on an experimental basis before poisoning mammals. Do not use traps, poisoned meat, or poisoned grain for rodent control when Burrowing Owls are present, but rather fumigate burrows unoccupied by owls (Butts 1973, Thomson 1988). However, be aware that it is difficult to determine which burrows are unoccupied once fledglings begin to use satellite burrows (M. J. Desmond, pers. comm.).

Increase the area of prairie dog colonies, possibly by reintroducing prairie dogs where they have been eliminated, or by releasing additional prairie dogs into active colonies to promote colony expansion (Pezzolesi 1994; Toombs 1997; T. I. Wellicome, pers. comm.). Colonies $\geq 35$ ha in area appeared to provide adequate space for nesting Burrowing Owls in Nebraska (Desmond et al. 1995; M. J. Desmond, pers. comm.).

Protect colonies and increase populations of burrowing mammals. In Saskatchewan, ground squirrels are an alternate prey source for all predators of Burrowing Owls; their presence may reduce predation pressures on Burrowing Owls (Butts 1973, Wedgwood 1976, Haug 1985, Ratcliff 1986, Stockrahm 1995, Wellicome et al. 1997). Preservation of large tracts of remaining prairies is crucial to preserving the prairie mammal community (Benedict et al. 1996). Tracts of fairly undisturbed prairie exist, especially in the central and western Great Plains. Burrows suitable for nesting owls are within active mammal colonies; abandonment by prairie dogs renders the habitat unsuitable for Burrowing Owls (Grant 1965; Butts 1973; Desmond and Savidge 1996, 1998, 1999).

Maintain abandoned prairie dog colonies at an early successional stage, with short $(<8 \mathrm{~cm})$ vegetation. Mowing can accomplish this, and would be critical around mid-March to improve nest-site attractiveness during nest initiation (Plumpton 1992, Plumpton and Lutz 1993). Mowing in mid- to late summer appears not to be detrimental to nesting owls (T. I. Wellicome, pers. comm.). However, mowing abandoned colonies may be effective only in the short term; burrows may require maintenance by prairie dogs to remain suitable for owls (MacCracken et al. 1985a, Desmond and Savidge 1999).

Preserve, restore, or enhance prey habitats such as road rights-of-way, hayland, and uncultivated areas of dense, tall vegetation within a 1-km radius of nesting areas (Haug 1985; Haug and Oliphant 1990; Pezzolesi 1994; Wellicome 1994, 1997a; Warnock 1997).

Plant permanent vegetation strips in heavily cultivated regions to increase habitat for rodent prey (Wellicome et al. 1997).

Implement rotational grazing in heavily grazed areas to increase prey populations (Wellicome et al. 1997). 
Table. Burrowing Owl habitat characteristics.

\begin{tabular}{|c|c|c|c|}
\hline Author(s) & Location(s) & Habitat(s) Studied* & Species-specific Habitat Characteristics \\
\hline Bent 1961 & Rangewide & $\begin{array}{l}\text { Colonies of burrowing } \\
\text { mammals, cropland, } \\
\text { mixed-grass pasture, } \\
\text { shortgrass pasture }\end{array}$ & $\begin{array}{l}\text { Used open, level prairie; preferred unbroken native sod } \\
\text { and avoided cultivated land; often nested in prairie dog } \\
\text { (Cynomys) or ground squirrel (Spermophilus) colonies }\end{array}$ \\
\hline Biddle 1996 & Colorado & $\begin{array}{l}\text { Colonies of burrowing } \\
\text { mammals, cropland, } \\
\text { hayland, idle shortgrass, } \\
\text { tame pasture }\end{array}$ & $\begin{array}{l}\text { Nested in black-tailed prairie dog (Cynomys ludovicianus) } \\
\text { colonies around which shortgrass patches were more } \\
\text { numerous than cropland patches, but due to small size, } \\
\text { shortgrass patches composed a smaller percentage of the } \\
\text { landscape than cropland patches by area; on average, } \\
\text { shortgrass patches were closer to the perimeter of black- } \\
\text { tailed prairie dog colonies than other patch types }\end{array}$ \\
\hline $\begin{array}{l}\text { Butts 1973, } \\
\text { Butts and Lewis } 1982\end{array}$ & Oklahoma & $\begin{array}{l}\text { Colonies of burrowing } \\
\text { mammals, cropland, idle, } \\
\text { idle mixed-grass, idle } \\
\text { shortgrass, mixed-grass } \\
\text { pasture, shortgrass } \\
\text { pasture }\end{array}$ & $\begin{array}{l}\text { Nested in shortgrass pasture or overgrazed mixed-grass } \\
\text { pasture where vegetation was } \leq 10 \mathrm{~cm} \text {; } 66 \% \text { of nests } \\
\text { occurred in black-tailed prairie dog colonies, though this } \\
\text { habitat represented }<20 \% \text { of habitat surveyed; use of } \\
\text { satellite burrows indicated a preference for habitat } \\
\text { conditions that existed only in prairie dog colonies; a few } \\
\text { nests were in wheat fields and edges of fallow fields; one } \\
\text { nest was in a sand sagebrush (Artemisia filifolia)/grass } \\
\text { pasture }\end{array}$ \\
\hline Clayton 1997 & $\begin{array}{l}\text { Alberta, } \\
\text { Saskatchewan }\end{array}$ & $\begin{array}{l}\text { Cropland, mixed-grass } \\
\text { pasture, tame pasture }\end{array}$ & $\begin{array}{l}\text { Preferred pastures with shorter grass; preferred both } \\
\text { native and tame pastures over cultivated land for nesting }\end{array}$ \\
\hline $\begin{array}{l}\text { Clayton and Schmutz } \\
1999\end{array}$ & $\begin{array}{l}\text { Alberta, } \\
\text { Saskatchewan }\end{array}$ & $\begin{array}{l}\text { Cropland, mixed-grass } \\
\text { pasture, tame pasture }\end{array}$ & $\begin{array}{l}\text { In Alberta, all nest sites ( } 100 \% \text { of } 21 \text { observations) and } \\
\text { roost sites ( } 100 \% \text { of } 275 \text { observations) were in native } \\
\text { pasture; the majority of roost sites also were located in }\end{array}$ \\
\hline
\end{tabular}




\begin{tabular}{|c|c|c|c|}
\hline & & & $\begin{array}{l}\text { native pasture, with only } 2 \% \text { of } 522 \text { observations } \\
\text { occurring in re-seeded pasture; within pastures, } \\
\text { Burrowing Owls preferred shorter }(\leq 10 \mathrm{~cm}) \text { grasses for } \\
\text { both nesting and roosting. In the Regina Plain, nest sites } \\
\text { and roost sites were nearly equally divided between } \\
\text { native pasture and re-seeded pasture; re-seeded pastures } \\
\text { were selected over native pastures for roosting when } \\
\text { availability of the different landuses was considered; in } \\
\text { cropland, owls did not selectively nest in short grass, but } \\
\text { also nested in strips of medium to tall grass between } \\
\text { fields and near ponds, granaries, and roads, possibly } \\
\text { because suitable habitat was lacking; foraged over areas } \\
\text { of tall vegetation }\end{array}$ \\
\hline $\begin{array}{l}\text { Desmond 1991; } \\
\text { Desmond and Savidge } \\
\text { 1996, 1999; Desmond et } \\
\text { al. } 1995\end{array}$ & Nebraska & $\begin{array}{l}\text { Colonies of burrowing } \\
\text { mammals, mixed-grass, } \\
\text { mixed-grass pasture, } \\
\text { shortgrass, shortgrass } \\
\text { pasture }\end{array}$ & $\begin{array}{l}\text { Nested in landscapes dominated by rangeland or } \\
\text { cropland; } 85 \% \text { of } 92 \text { nests occurred in black-tailed prairie } \\
\text { dog colonies, and } 15 \% \text { in American badger (Taxidea } \\
\text { taxus) excavations; successful nests within black-tailed } \\
\text { prairie dog colonies had more active (i.e., occupied by } \\
\text { prairie dogs) burrows within } 75 \text { m of the nest burrow than } \\
\text { did unsuccessful nests; chicks preferred active over } \\
\text { inactive satellite burrows; prairie dog colony size was } \\
\text { positively correlated with number of Burrowing Owl } \\
\text { young fledged per pair; colonies } \geq 35 \text { ha appeared to } \\
\text { provide adequate space requirements for nesting owls }\end{array}$ \\
\hline Faanes and Lingle 1995 & Nebraska & $\begin{array}{l}\text { Colonies of burrowing } \\
\text { mammals, mixed-grass } \\
\text { hayland, mixed-grass } \\
\text { pasture, shortgrass } \\
\text { hayland, shortgrass } \\
\text { pasture }\end{array}$ & $\begin{array}{l}\text { Nested only in uplands; preferred heavily grazed or } \\
\text { mowed native prairie; were usually associated with black- } \\
\text { tailed prairie dog colonies }\end{array}$ \\
\hline
\end{tabular}




\begin{tabular}{|c|c|c|c|}
\hline $\begin{array}{l}\text { Gleason 1978, } \\
\text { Gleason and Johnson } \\
1985\end{array}$ & Idaho & $\begin{array}{l}\text { Idle, shrubsteppe pasture, } \\
\text { tame hayland, tame } \\
\text { pasture }\end{array}$ & $\begin{array}{l}\text { Preferred open, shrubless areas; used American badger } \\
\text { excavations and natural basalt cavities for nest sites; } \\
\text { seven of nine nests were adjacent to alfalfa (Medicago } \\
\text { sativa) fields (locations of the remaining two nests were } \\
\text { not given) }\end{array}$ \\
\hline Grant 1965 & $\begin{array}{l}\text { Minnesota, } \\
\text { North Dakota, } \\
\text { South Dakota }\end{array}$ & $\begin{array}{l}\text { Colonies of burrowing } \\
\text { mammals, cropland, idle, } \\
\text { idle shortgrass, mixed- } \\
\text { grass pasture, tallgrass } \\
\text { pasture }\end{array}$ & $\begin{array}{l}\text { Preferred closely cropped, flat to slightly rolling, well } \\
\text { drained pastures inhabited by Richardson's ground } \\
\text { squirrels (Spermophilus richardsonii); nest sites always } \\
\text { included a nearby perch }\end{array}$ \\
\hline Green and Anthony 1989 & Oregon & $\begin{array}{l}\text { Shrubsteppe pasture, } \\
\text { tame }\end{array}$ & $\begin{array}{l}\text { Nested in American badger excavations in open areas of } \\
\text { short vegetation dominated by snakeweed (Gutierrezia } \\
\text { sarothrae), downy brome (Bromus tectorum), or antelope } \\
\text { bitterbrush (Purshia tridentata); did not nest in habitats } \\
\text { dominated by rabbitbrush (Chrysothamnus nauseosus) or } \\
\text { bunchgrasses; required perches where vegetation was }>5 \\
\text { cm tall; required manure as nest lining; mean habitat } \\
\text { values in downy brome were } 85.9 \mathrm{~cm} \text { perch height, } 28 \% \\
\text { grass cover, and } 54.8 \% \text { bare ground; mean vegetation } \\
\text { measurements in snakeweed were } 4.7 \mathrm{~cm} \text { effective } \\
\text { vegetation height, } 49 \% \text { bare ground, and } 36 \% \text { grass cover }\end{array}$ \\
\hline $\begin{array}{l}\text { Haug 1985; } \\
\text { Haug and Oliphant 1987, } \\
1990\end{array}$ & Saskatchewan & $\begin{array}{l}\text { Colonies of burrowing } \\
\text { mammals, cropland, idle, } \\
\text { idle mixed-grass, idle } \\
\text { mixed-grass pasture, } \\
\text { mixed-grass pasture, } \\
\text { tame hayland, tame } \\
\text { pasture, wetland }\end{array}$ & $\begin{array}{l}\text { Most nests were in American badger excavations; other } \\
\text { nests were in Richardson's ground squirrel burrows; } \\
\text { nested in open areas in small pastures with short grass and } \\
\text { an average of six available burrows within } 30 \text { m of the } \\
\text { nest; nests in tame pasture were more successful than } \\
\text { nests in native pasture; foraged in grass/forb areas more } \\
\text { than expected by chance; avoided cropland and native } \\
\text { pasture }\end{array}$ \\
\hline
\end{tabular}




\begin{tabular}{|c|c|c|c|}
\hline Hughes 1993 & Colorado & $\begin{array}{l}\text { Colonies of burrowing } \\
\text { mammals, cropland, } \\
\text { hayland, idle shortgrass, } \\
\text { tame pasture }\end{array}$ & $\begin{array}{l}\text { Nested in prairie dog colonies from } 1.9 \text { to } 168 \text { ha in size; } \\
\geq 50 \% \text { of burrows were active in } 26 \text { of } 27 \text { colonies } \\
\text { containing owls }\end{array}$ \\
\hline James et al. 1990 & Saskatchewan & $\begin{array}{l}\text { Colonies of burrowing } \\
\text { mammals, tame pasture }\end{array}$ & $\begin{array}{l}\text { Nested in Richardson's ground squirrel burrows in } \\
\text { heavily grazed, tame pastures }\end{array}$ \\
\hline $\begin{array}{l}\text { James and Seabloom } \\
1968\end{array}$ & North Dakota & $\begin{array}{l}\text { Colonies of burrowing } \\
\text { mammals, mixed-grass } \\
\text { pasture }\end{array}$ & $\begin{array}{l}\text { Nested in prairie dog burrows and American badger } \\
\text { excavations on level ground or on well-drained slopes in } \\
\text { mixed-grass pastures }\end{array}$ \\
\hline Kantrud 1981 & North Dakota & $\begin{array}{l}\text { Mixed-grass hayland, } \\
\text { mixed-grass pasture }\end{array}$ & Occurred only in moderately or heavily grazed pastures \\
\hline $\begin{array}{l}\text { Kantrud and Kologiski } \\
1982\end{array}$ & $\begin{array}{l}\text { Colorado, } \\
\text { Montana, } \\
\text { Nebraska, } \\
\text { North Dakota, } \\
\text { South Dakota, } \\
\text { Wyoming }\end{array}$ & $\begin{array}{l}\text { Mixed-grass pasture, } \\
\text { shortgrass pasture }\end{array}$ & $\begin{array}{l}\text { Used heavily grazed areas with aridic ustoll soils and } \\
\text { grazed areas with typic boroll soils }\end{array}$ \\
\hline Konrad and Gilmer 1984 & North Dakota & $\begin{array}{l}\text { Colonies of burrowing } \\
\text { mammals, idle tame, } \\
\text { mixed-grass pasture }\end{array}$ & $\begin{array}{l}\text { Preferred heavily grazed, mixed-grass pasture containing } \\
\text { colonies of Richardson's ground squirrels }\end{array}$ \\
\hline MacCracken et al. 1985a & South Dakota & $\begin{array}{l}\text { Colonies of burrowing } \\
\text { mammals, shortgrass } \\
\text { pasture }\end{array}$ & $\begin{array}{l}\text { Nested in black-tailed prairie dog burrows with } \\
\text { vegetation shorter than that in the rest of the colony; mean } \\
\text { vegetation coverages at nest burrows were } 42 \% \text { bare } \\
\text { ground, } 16 \% \text { litter, } 35 \% \text { grasses and sedges (Carex spp.), } \\
45 \% \text { forbs, } 1 \% \text { shrubs, and } 1 \% \text { plains prickly pear } \\
\text { (Opuntia polyacantha); average maximum vegetation } \\
\text { height was } 13 \mathrm{~cm} \text {; soil samples at nest burrow had } 29 \% \\
\text { sand, } 43 \% \text { silt, and } 31 \% \text { clay }\end{array}$ \\
\hline
\end{tabular}




\begin{tabular}{|c|c|c|c|}
\hline Martin 1983 & Wyoming & $\begin{array}{l}\text { Colonies of burrowing } \\
\text { mammals }\end{array}$ & $\begin{array}{l}\text { Owls preferred black-tailed over white-tailed prairie dog } \\
\text { (Cynomys leucurus) colonies because the former were } \\
\text { more open and had shorter vegetation }\end{array}$ \\
\hline Pezzolesi 1994 & Colorado & $\begin{array}{l}\text { Colonies of burrowing } \\
\text { mammals, idle } \\
\text { shortgrass, idle tame }\end{array}$ & $\begin{array}{l}\text { All nesting attempts took place in active colonies of } \\
\text { black-tailed prairie dogs }\end{array}$ \\
\hline Plumpton 1992 & Colorado & $\begin{array}{l}\text { Colonies of burrowing } \\
\text { mammals, idle } \\
\text { shortgrass, idle tame }\end{array}$ & $\begin{array}{l}\text { Nested in black-tailed prairie dog burrows that were } \\
\text { farther (mean of } 11 \mathrm{~m} \text { ) than expected from nearest perch; } \\
\text { grass height was shorter at nest sites (mean of } 7.3 \mathrm{~cm} \text { ) } \\
\text { than at non-nest sites; mean vegetation characteristics } \\
\text { around nests were } 12 \% \text { grass cover, } 30 \% \text { forb cover, } 58 \% \\
\text { bare ground, and } 6.7 \mathrm{~cm} \text { forb height }\end{array}$ \\
\hline Plumpton and Lutz 1993 & Colorado & $\begin{array}{l}\text { Colonies of burrowing } \\
\text { mammals, idle } \\
\text { shortgrass, idle tame }\end{array}$ & $\begin{array}{l}\text { Used burrows in black-tailed prairie dog colonies with } \\
\text { greater amounts of bare ground and shorter grasses and } \\
\text { forbs than occurred at unused burrows; vegetation } \geq 8 \mathrm{~cm} \\
\text { tall around burrows was detrimental to owl populations }\end{array}$ \\
\hline Rich 1984, 1986 & Idaho & $\begin{array}{l}\text { Cropland, idle } \\
\text { semidesert shrubsteppe, } \\
\text { semidesert shrubsteppe } \\
\text { pasture }\end{array}$ & $\begin{array}{l}\text { Nested in abandoned yellow-bellied marmot (Marmota } \\
\text { flaviventris) burrows, in lava outcrops, and in American } \\
\text { badger excavations; nested in outcrop burrows more than } \\
\text { expected based on availability; preferred small lava } \\
\text { outcrops over large; downy brome cover within } 50 \text { m of } \\
\text { burrows was higher at nest sites than at non-nest sites; the } \\
\text { percentages of bare ground, rock cover, and annual forb } \\
\text { cover were high at nest sites; nest sites often had } \\
\text { southerly aspects }\end{array}$ \\
\hline Schmutz 1997 & Alberta & $\begin{array}{l}\text { Colonies of burrowing } \\
\text { mammals, cropland, } \\
\text { mixed-grass pasture }\end{array}$ & $\begin{array}{l}\text { More nests were located }>0.5 \mathrm{~km} \text { from croplands than } \\
\text { expected by chance }\end{array}$ \\
\hline
\end{tabular}




\begin{tabular}{|c|c|c|c|}
\hline Scott 1940 & Iowa & $\begin{array}{l}\text { Cropland, tame hayland, } \\
\text { pasture }\end{array}$ & $\begin{array}{l}\text { Nested in American badger excavations within } \\
\text { agricultural landscapes; cow or horse manure was used to } \\
\text { line nests; one nest was in an alfalfa field; one nest was in } \\
\text { moderately grazed pasture; one nest was in heavily grazed } \\
\text { pasture }\end{array}$ \\
\hline Stewart 1975 & North Dakota & $\begin{array}{l}\text { Colonies of burrowing } \\
\text { mammals, mixed-grass } \\
\text { pasture }\end{array}$ & $\begin{array}{l}\text { Preferred heavily grazed mixed-grass pastures with high } \\
\text { densities of Richardson's ground squirrels or black-tailed } \\
\text { prairie dogs }\end{array}$ \\
\hline Stockrahm 1995 & North Dakota & $\begin{array}{l}\text { Colonies of burrowing } \\
\text { mammals, mixed-grass }\end{array}$ & $\begin{array}{l}\text { Nested in black-tailed prairie dog colonies; plant species } \\
\text { near burrows were blue grama (Bouteloua gracilis), } \\
\text { bluegrass (Poa spp.), inland saltgrass (Distichlis spicata), } \\
\text { Junegrass (Koeleria pyramidata), needle-and-thread } \\
\text { (Stipa comata), sedge, smooth brome (Bromus inermis), } \\
\text { western wheatgrass (Pascopyrum smithii), knotweed } \\
\text { (Polygonum sp.), pigweed (Amaranthus spp.), sagebrush } \\
\text { (Artemisia spp.), yellow sweet clover (Melilotus } \\
\text { officinalis), and prairie wild rose (Rosa arkansana); } \\
\text { vegetation in the vicinity of nest burrows was always <31 } \\
\text { cm tall, and sparse; mean values for burrow mound } \\
\text { characteristics were } 144 \text { cm mound diameter, } 12 \text { cm } \\
\text { entrance diameter, } 34 \text { cm mound height, and } 7.8 \text { m mean } \\
\text { distance from the four nearest non-nest burrows }\end{array}$ \\
\hline Thompson 1984 & Wyoming & $\begin{array}{l}\text { Colonies of burrowing } \\
\text { mammals, cropland, } \\
\text { shortgrass pasture, tame } \\
\text { hayland }\end{array}$ & $\begin{array}{l}\text { Nested only in black-tailed or white-tailed prairie dog } \\
\text { colonies; mean values at nest sites were } 29-37 \% \text { forb } \\
\text { cover, } 24-30 \% \text { grass and sedge cover, } 1-4 \% \text { shrub cover, } \\
6-10 \% \text { litter cover, } 25-33 \% \text { bare ground; distance to } \\
\text { nearest potential nesting burrow was } 8-10 \text { m; soil was } \\
\text { composed of } 30-34 \% \text { sand, } 42-46 \% \text { silt, and } 20-28 \% \text { clay }\end{array}$ \\
\hline Thompson and Anderson & Wyoming & Colonies of burrowing & Nested and foraged within active colonies either of black- \\
\hline
\end{tabular}




\begin{tabular}{|l|l|l|l|}
\hline 1988 & Colorado & $\begin{array}{l}\text { mammals, cropland, idle, } \\
\text { idle shortgrass }\end{array}$ & $\begin{array}{l}\text { tailed or white-tailed prairie dogs; foraged within } \\
\text { cropland, fallow fields, and sparsely vegetated areas }\end{array}$ \\
\hline Toombs 1997 & $\begin{array}{l}\text { mammals, idle } \\
\text { shortgrass, shortgrass } \\
\text { pasture }\end{array}$ & $\begin{array}{l}\text { Nested at the edges of active black-tailed prairie dog } \\
\text { colonies in areas of high burrow density; occupied } \\
\text { colonies had higher mean total burrow density (101 } \\
\text { burrows/ha), higher mean active burrow density (46 } \\
\text { burrows /ha), and higher mean percent active burrows } \\
\text { (43\%) than unoccupied colonies }\end{array}$ \\
\hline $\begin{array}{l}\text { Warnock and James } \\
\text { 1996, 1997 }\end{array}$ & Saskatchewan & $\begin{array}{l}\text { Cropland, mixed-grass } \\
\text { pasture }\end{array}$ & $\begin{array}{l}\text { Sites used by owls were less isolated from other owl- } \\
\text { occupied sites than random sites; sites reused in } \\
\text { subsequent years had more nearby owl-occupied sites } \\
\text { than those not reused; ideal nesting habitat occurred in } \\
\text { high quality lacustrine (i.e., ancient lake-bottom) soils }\end{array}$ \\
\hline Wedgwood 1976 & Saskatchewan & $\begin{array}{l}\text { Colonies of burrowing } \\
\text { mammals, cropland, idle } \\
\text { mixed-grass, idle } \\
\text { shortgrass, mixed-grass } \\
\text { pasture, shortgrass } \\
\text { pasture, tame pasture }\end{array}$ & $\begin{array}{l}\text { Nested in level to gently rolling shortgrass pastures } \\
\text { containing ground squirrel burrows or American badger } \\
\text { excavations; most owls nested in American badger } \\
\text { excavations; preferred heavily grazed areas of poor soil; } \\
\text { avoided woody vegetation, tilled ground, and tame } \\
\text { pastures }\end{array}$ \\
\hline
\end{tabular}

*In an effort to standardize terminology among studies, various descriptors were used to denote the management or type of habitat. "Idle" used as a modifier (e.g., idle tallgrass) denotes undisturbed or unmanaged (e.g., not burned, mowed, or grazed) areas. "Idle" by itself denotes unmanaged areas in which the plant species were not mentioned. Examples of "idle" habitats include weedy or fallow areas (e.g., oldfields), fencerows, grassed waterways, terraces, ditches, and road rights-of-way. "Tame” denotes introduced plant species (e.g., smooth brome [Bromus inermis]) that are not native to North American prairies. "Hayland" refers to any habitat that was mowed, regardless of whether the resulting cut vegetation was removed. "Burned" includes habitats that were burned intentionally or accidentally or those burned by natural forces (e.g., lightning). In situations where there are two or more descriptors (e.g., idle tame hayland), the first descriptor modifies the following descriptors. For example, idle tame hayland is habitat that is usually mowed annually but happened to be undisturbed during the year of the study. 


\section{LITERATURE CITED}

Arrowood, P. C., C. A. Finley, B. C. Thompson, and E. S. Botelho. 1998. Residency, recruitment, return and reproduction in Burrowing Owls in southern New Mexico. Page 6 in Abstracts of the Second International Burrowing Owl Symposium, Ogden, Utah.

Barclay, J., C. Bean, D. Plumpton, B. Walton, and the California Burrowing Owl Consortium. 1998. Burrowing Owl conservation in California: issues and challenges. Page 7 in Abstracts of the Second International Burrowing Owl Symposium, Ogden, Utah.

Baril, A. 1993. Pesticides and wildlife in the prairies: current regulatory issues. Pages 44-48 in G. L. Holroyd, H. L. Dickson, M. Regnier, and H. C. Smith, editors. Proceedings of the third endangered species and prairie conservation workshop. Natural History Occasional Paper 19. Provincial Museum of Alberta, Edmonton, Alberta.

Benedict, R. A., P. W. Freeman, and H. H. Genoways. 1996. Prairie legacies--mammals. Pages 149-167 in F. B. Samson and F. L. Knopf, editors. Prairie conservation: preserving North America's most endangered ecosystem. Island Press, Covelo, California.

Bent, A. C. 1961. Life histories of North American birds of prey, part 2. Dover Publications, Inc., New York, New York. 482 pages.

Berdan, C. A., and R. L. Linder. 1973. Burrowing Owls in Mellette County, South Dakota. South Dakota Bird Notes 26:26-27.

Berkey, G., R. Crawford, S. Galipeau, D. Johnson, D. Lambeth, and R. Kreil. 1993. A review of wildlife management practices in North Dakota: effects on nongame bird populations and habitats. Report submitted to Region 6. U.S. Fish and Wildlife Service, Denver, Colorado. 51 pages.

Biddle, P. B. 1996. Do landuse patterns influence Burrowing Owl nest site selection in northeastern Colorado? M.S. thesis. Colorado State University, Fort Collins, Colorado. 45 pages.

Bock, C. E., V. A. Saab, T. D. Rich, and D. S. Dobkin. 1993. Effects of livestock grazing on Neotropical migratory landbirds in western North America. Pages 296-309 in D. M. Finch and P. W. Stangel, editors. Status and management of Neotropical migratory birds. U.S.D.A. Forest Service, General Technical Report RM-229.

Bue, G. T. 1955. Recent observations of Burrowing Owls in Lyon and Yellow Medicine counties, Minnesota. Flicker 27:40-41.

Butts, K. O. 1973. Life history and habitat requirements of Burrowing Owls in western Oklahoma. M.S. thesis. Oklahoma State University, Stillwater, Oklahoma. 188 pages.

Butts, K. O., and J. C. Lewis. 1982. The importance of prairie dog towns to Burrowing Owls in Oklahoma. Proceedings of the Oklahoma Academy of Science 62:46-52. 
Clark, T. W., T. W. Campbell III, D. G. Socha, and D. E. Cassey. 1982. Prairie dog colony attributes and associated vertebrate species. Great Basin Naturalist 42:572-582.

Clayton, K. M. 1997. Post-fledging ecology of Burrowing Owls in Alberta and Saskatchewan: dispersal, survival, habitat use, and diet. M.S. thesis. University of Saskatchewan, Saskatoon, Saskatchewan. 66 pages.

Clayton, K. M., and J. K. Schmutz. 1999. Is the decline of Burrowing Owls Speotyto cunicularia in prairie Canada linked to changes in Great Plains ecosystems? Bird Conservation International 9:163-185.

De Smet, K. D. 1992. Manitoba's threatened and endangered grassland birds: 1991 update and five-year summary. Manuscript report 92-03, Manitoba Natural Resources, Winnipeg, Manitoba. 77 pages.

De Smet, K. D. 1997. Burrowing Owl (Speotyto cunicularia) monitoring and management activities in Manitoba, 1987-1996. Pages 123-130 in J. R. Duncan, D. H. Johnson, and T. H. Nicholls, editors. Biology and conservation of owls of the Northern Hemisphere: Second International Symposium. U.S.D.A., Forest Service General Technical Report NC-190, North Central Forest Experiment Station.

Delevoryas, P. 1997. Relocation of Burrowing Owls during courtship period. Pages 138-144 in J. L. Lincer and K. Steenhof, editors. The Burrowing Owl, its biology and management: including the Proceedings of the First International Symposium. Raptor Research Report Number 9.

Desmond, M. J. 1991. Ecological aspects of Burrowing Owl nesting strategies in the Nebraska panhandle. M.S. thesis. University of Nebraska, Lincoln, Nebraska. 114 pages.

Desmond, M. J., and J. A. Savidge. 1996. Factors influencing Burrowing Owl (Speotyto cunicularia) nest densities and numbers in western Nebraska. American Midland Naturalist 136:143-148.

Desmond, M. J., and J. A. Savidge. 1998. Burrowing Owl conservation in the Great Plains. Page 9 in Abstracts of the Second International Burrowing Owl Symposium, Ogden, Utah.

Desmond, M. J., and J. A. Savidge. 1999. Satellite burrow use by Burrowing Owl chicks and its influence on nest fate. In P. D. Vickery and J. R. Herkert, editors. Ecology and conservation of grassland birds in the western hemisphere. Studies in Avian Biology 19.

Desmond, M. J., J. A. Savidge, and R. Ekstein. 1997. Prairie partners. NEBRASKAland 75:1625.

Desmond, M. J., J. A. Savidge, and K. M. Eskridge. 2000. Correlations between Burrowing Owl and Black-tailed Prairie Dog declines: A 7-year analysis. Journal of Wildlife Management 64:1067-1075. 
Desmond, M. J., J. A. Savidge, and T. F. Seibert. 1995. Spatial patterns of Burrowing Owl (Speotyto cunicularia) nests within black-tailed prairie dog (Cynomys ludovicianus) towns. Canadian Journal of Zoology 73:1375-1379.

Evans, D. L. 1982. Status reports on twelve raptors. Special Scientific Report-Wildlife, No. 238. U.S. Fish and Wildlife Service, Washington, D.C. 70 pages.

Faanes, C. A., and G. R. Lingle. 1995. Breeding birds of the Platte River Valley of Nebraska. Jamestown, ND: Northern Prairie Wildlife Research Center home page. http://www.npwrc.usgs.gov/resource/distr/birds/platte/platte.htm (Version 16JUL97).

Feeney, L. R. 1997. Burrowing Owl site tenacity associated with relocation efforts. Pages 132137 in J. L. Lincer and K. Steenhof, editors. The Burrowing Owl, its biology and management: including the Proceedings of the First International Symposium. Raptor Research Report Number 9.

Fox, G. A., P. Mineau, B. Collins, and P. C. James. 1989. The impact of the insecticide carbofuran (Furadan 480F) on the Burrowing Owl in Canada. Technical Report Series No. 72. Canadian Wildlife Service, Ottawa, Canada. 21+ pages.

Gleason, R. S. 1978. Aspects of the breeding biology of Burrowing Owls in southeastern Idaho. M.S. thesis. University of Idaho, Moscow, Idaho. 47 pages.

Gleason, R. S., and D. R. Johnson. 1985. Factors influencing nesting success of Burrowing Owls in southeastern Idaho. Great Basin Naturalist 45:81-84.

Grant, R. A. 1963. A colony of Burrowing Owls at Watford City, North Dakota. South Dakota Bird Notes 15:92.

Grant, R. A. 1965. The Burrowing Owl in Minnesota. Loon 37:2-17.

Green, G. A., and R. G. Anthony. 1989. Nesting success and habitat relationships of Burrowing Owls in the Columbia Basin, Oregon. Condor 91:347-354.

Green, G. A., and R. G. Anthony. 1997. Ecological considerations for management of breeding Burrowing Owls in the Columbia Basin. Pages 117-121 in J. L. Lincer and K. Steenhof, editors. The Burrowing Owl, its biology and management: including the Proceedings of the First International Symposium. Raptor Research Report Number 9.

Hall, W. 1961. Burrowing Owls, vanishing birds on the vanishing prairie. South Dakota Bird Notes 13:29-35.

Haug, E. A. 1985. Observations on the breeding ecology of Burrowing Owls in Saskatchewan. M.S. thesis. University of Saskatchewan, Saskatoon, Saskatchewan. 89 pages.

Haug, E. A., B. A. Millsap, and M. S. Martell. 1993. Burrowing Owl (Speotyto cunicularia). In A. Poole and F. Gill, editors. The birds of North America, No. 61. The Academy of 
Natural Sciences, Philadelphia, Pennsylvania; The American Ornithologists’ Union, Washington, D.C.

Haug, E. A., and L. W. Oliphant. 1987. Breeding biology of Burrowing Owls in Saskatchewan. Pages 269-271 in G. L. Holroyd, P. H. R. Stepney, G. C. Trottier, W. B. McGillivray, D. M. Ealey, and K. E. Eberhart, editors. Endangered species in the prairie provinces. Natural History Occasional Paper No. 9. Provincial Museum of Alberta, Edmonton, Alberta.

Haug, E., and L. W. Oliphant. 1990. Movements, activity patterns, and habitat use of Burrowing Owls in Saskatchewan. Journal of Wildlife Management 54:27-35.

Hjertaas, D. 1993. The Burrowing Owl recovery program. Pages 350-352 in G. L. Holroyd, H. L. Dickson, M. Regnier, and H. C. Smith, editors. Proceedings of the third endangered species and prairie conservation workshop. Natural History Occasional Paper 19. Provincial Museum of Alberta, Edmonton, Alberta.

Hjertaas, D. G. 1997a. Recovery plan for the Burrowing Owl in Canada. Pages 107-111 in J. L. Lincer and K. Steenhof, editors. The Burrowing Owl, its biology and management: including the Proceedings of the First International Symposium. Raptor Research Report Number 9.

Hjertaas, D. G. 1997b. Operation Burrowing Owl in Saskatchewan. Pages 112-116 in J. L. Lincer and K. Steenhof, editors. The Burrowing Owl, its biology and management: including the Proceedings of the First International Symposium. Raptor Research Report Number 9.

Hughes, A. J. 1993. Breeding density and habitat preference of the Burrowing Owl in northeastern Colorado. M.S. thesis. Colorado State University, Fort Collins, Colorado. 28 pages.

James, P. C. 1993. Habitat fragmentation and Burrowing Owls in Saskatchewan. Pages 193194 in G. L Holroyd, H. L. Dickson, M. Regnier, and H. C. Smith, editors. Proceedings of the third endangered species and prairie conservation workshop. Natural History Occasional Paper 19. Provincial Museum of Alberta, Edmonton, Alberta.

James, P. C., T. J. Ethier, and M. K. Toutloff. 1997. Parameters of a declining Burrowing Owl population in Saskatchewan. Pages 34-37 in J. L. Lincer and K. Steenhof, editors. The Burrowing Owl, its biology and management: including the Proceedings of the First International Symposium. Raptor Research Report Number 9.

James, P. C., and G. A. Fox. 1987. Effects of some insecticides on productivity of Burrowing Owls. Blue Jay 45:65-71.

James, P. C., G A. Fox, and T. J. Ethier. 1990. Is the operational use of strychnine to control ground squirrels detrimental to Burrowing Owls? Journal of Raptor Research 24:120123. 
James, T. R., and R. W. Seabloom. 1968. Notes on the burrow ecology and food habits of the Burrowing Owl in southwestern North Dakota. Blue Jay 26:83-84.

John, R. D., and J. Romanow. 1993. Feeding behaviour of a Burrowing Owl, Athene cunicularia, in Ontario. Canadian Field-Naturalist 107:231-232.

Kantrud, H. A. 1981. Grazing intensity effects on the breeding avifauna of North Dakota native grasslands. Canadian Field-Naturalist 95:404-417.

Kantrud, H. A., and R. L. Kologiski. 1982. Effects of soils and grazing on breeding birds of uncultivated upland grasslands of the northern Great Plains. U.S. Fish and Wildlife Service, Wildlife Research Report 15. 33 pages.

Konrad, P. M., and D. S. Gilmer. 1984. Observations on the nesting ecology of Burrowing Owls in central North Dakota. Prairie Naturalist 16:129-130.

Low, D., and E. E. Leupin. 1998. An assessment of the Burrowing Owl re-introduction in the Thompson/Nicola region of British Columbia: a summary report (1992-1997). Page 17 in Abstracts of the Second International Burrowing Owl Symposium, Ogden, Utah.

Lutz, R. S., and D. L. Plumpton. 1999. Philopatry and nest site reuse by Burrowing Owls: implications for productivity. Journal of Raptor Research 33:149-153.

MacCracken, J. G., D. W. Uresk, and R. M. Hansen. 1984. Burrowing Owl nesting habitat use in Conata Basin, South Dakota. Abstracts of the Society for Range Management 37th Annual Meeting, Rapid City, South Dakota.

MacCracken, J. G., D. W. Uresk, and R. M. Hansen. 1985a. Vegetation and soils of Burrowing Owl nest sites in Conata Basin, South Dakota. Condor 87:152-154.

MacCracken, J. G., D. W. Uresk, and R. M. Hansen. 1985b. Burrowing Owl foods in Conata Basin, South Dakota. Great Basin Naturalist 45:287-290.

Maher, W. J. 1974. Matador Project: Birds II. Avifauna of the Matador area. Canadian Committee for the International Biological Programme, Matador Project, Technical Report 58. University of Saskatchewan, Saskatoon, Saskatchewan. 31 pages.

Martell, M. S., J. Schladweiler, and F. Cuthbert. 1998. The status and reintroduction of Burrowing Owls in Minnesota, USA. Pages 17-18 in Abstracts of the Second International Burrowing Owl Symposium, Ogden, Utah.

Martin, D. J. 1973. Selected aspects of Burrowing Owl ecology and behavior. Condor 75:446456.

Martin, S. J. 1983. Burrowing Owl occurrence on white-tailed prairie dog colonies. Journal of Field Ornithology 54:422-423. 
Murphy, R. K. 1993. History, nesting biology, and predation ecology of raptors in the Missouri Coteau of northwestern North Dakota. Ph.D. dissertation. Montana State University, Bozeman, Montana. 212 pages.

Murphy, R. K., K. W. Hasselblad, C. D. Grondahl, J. G. Sidle, R. E. Martin, and D. W. Freed. 2001. Status of the Burrowing Owl in North Dakota. Journal of Raptor Research 35:322-330.

National Geographic Society. 1987. Field guide to the birds of North America, second edition. National Geographic Society, Washington, D.C. 464 pages.

Olendorff, R. R. 1973. The ecology of the nesting birds of prey of northeastern Colorado. U.S. International Biological Program, Grassland Biome Technical Report 211. Colorado State University, Fort Collins, Colorado. 233 pages.

Otnes, G. L. 1980. Burrowing Owls, Clay County. Loon 52:116.

Pest Management Regulatory Agency (PMRA). 1995. Carbofuran. Decision Document E9505. PMRA, Health Canada, Ottawa, Ontario. 11 pages.

Pezzolesi, L. S. W. 1994. The western Burrowing Owl: increasing prairie dog abundance, foraging theory, and nest site fidelity. M.S. thesis. Texas Tech University, Lubbock, Texas. 65 pages.

Plumpton, D. L. 1992. Aspects of nest site selection and habitat use by Burrowing Owls at the Rocky Mountain Arsenal, Colorado. M.S. thesis. Texas Technical University, Lubbock, Texas. 72 pages.

Plumpton, D., and R. S. Lutz. 1991. Nest site selection by Burrowing Owls in Colorado. Journal of Raptor Research 25:158-159.

Plumpton, D. L., and R. S. Lutz. 1993. Nesting habitat use by Burrowing Owls in Colorado. Journal of Raptor Research 27:175-179.

Plumpton, D. L., and R. S. Lutz. 1998. Philopatry and nest site reuse by Burrowing Owls: implications for productivity. Page 19 in Abstracts of the Second International Burrowing Owl Symposium, Ogden, Utah.

Poulin, R. G., T. I. Wellicome, and L. D. Todd. 1998. Lagged response of Burrowing Owls and the overall responses of prairie raptor populations to a vole outbreak. Page 20 in Abstracts of the Second International Burrowing Owl Symposium, Ogden, Utah.

Ratcliff, B. D. 1986. The Manitoba Burrowing Owl survey, 1982-1984. Blue Jay 44:31-37.

Rich, T. 1984. Monitoring Burrowing Owl populations: implications of burrow re-use. Wildlife Society Bulletin 12:178-180. 
Rich, T. 1986. Habitat and nest-site selection by Burrowing Owls in the sagebrush steppe of Idaho. Journal of Wildlife Management 50:548-555.

Richards, W. S. 1972. The railway--a hazard to birds. Blue Jay 30:48-49.

Salt, W. R., and A. L. Wilk. 1958. The birds of Alberta. Department of Economic Affairs, Edmonton, Alberta. 295 pages.

Schmutz, J. K. 1993. Is the density of Burrowing Owls breeding in Alberta limited by habitat? Journal of Raptor Research 27:63.

Schmutz, J. K. 1997. Selected microhabitat variables near nests of Burrowing Owls compared to unoccupied sites in Alberta. Pages 80-83 in J. L. Lincer and K. Steenhof, editors. The Burrowing Owl, its biology and management: including the Proceedings of the First International Symposium. Raptor Research Report Number 9.

Schmutz, J. K., and D. C. Moody. 1989. Habitat use by Burrowing Owls near Hanna. Pages 917 in J. K. Schmutz, editor. Conservation biology of Burrowing Owls: survival, habitat use and differences between populations. Unpublished Annual Report. University of Saskatchewan, Saskatoon, Saskatchewan.

Schmutz, J. K., G. Wood, and D. Wood. 1989. Survival of breeding Burrowing Owls. Pages 49 in J. K. Schmutz, editor. Conservation biology of Burrowing Owls: survival, habitat use and differences between populations. Unpublished Annual Report. University of Saskatchewan, Saskatoon, Saskatchewan.

Schmutz, J. K., G. Wood, and D. Wood. 1991. Spring and summer prey of Burrowing Owls in Alberta. Blue Jay 49:93-97.

Scott, T. G. 1940. The Western Burrowing Owl in Clay County, Iowa, in 1938. American Midland Naturalist 24:585-593.

Sidle, J. G., M. Ball, T. Byer, J. Chynoweth, G. Foli, R. Hodorff, G. Moravek, R. Peterson, and D. Svingen. 1998. Occurrence of Burrowing Owls on Great Plains National Grasslands. Page 22 in Abstracts of the Second International Burrowing Owl Symposium, Ogden, Utah.

Sissons, R., K. Scalise, and T. I. Wellicome. 1998. Nocturnal foraging habitat use of the Burrowing Owl in a heavily cultivated region of southern Saskatchewan. Pages 22-23 in Abstracts of the Second International Burrowing Owl Symposium, Ogden, Utah.

Stewart, R. E. 1975. Breeding birds of North Dakota. Tri-College Center for Environmental Studies, Fargo, North Dakota. 295 pages.

Stockrahm, D. M. B. 1995. Distribution of the Burrowing Owl (Athene cunicularia) in Billings County, North Dakota. Unpublished report. Moorhead State University, Moorhead, Minnesota. 40 pages. 
Stoner, E. A. 1932. Notes on the Western Burrowing Owl. Condor 34:228-229.

Thompson, C. D. 1984. Selected aspects of Burrowing Owl ecology in central Wyoming. M.S. thesis. University of Wyoming, Laramie, Wyoming. 45 pages.

Thompson, C. D., and S. H. Anderson. 1988. Foraging behavior and food habits of Burrowing Owls in Wyoming. Prairie Naturalist 20:23-28.

Thomson, K. A. 1988. Management of Burrowing Owls in Manitoba, population distribution and plan for recovery. M.S. thesis. Natural Resource Institute, University of Manitoba, Winnipeg, Manitoba. 75 pages.

Todd, L. D. 1998. Post-fledging dispersal and mortality of juvenile Burrowing Owls in on [sic] the Regina Plain, Saskatchewan: preliminary results. Page 24 in Abstracts of the Second International Burrowing Owl Symposium, Ogden, Utah.

Toombs, T. P. 1997. Burrowing Owl nest-site selection in relation to soil texture and prairie dog colony attributes. M.S. thesis. Colorado State University, Fort Collins, Colorado. 73 pages.

Tyler, J. D. 1983. Notes on the Burrowing Owl food habits in Oklahoma. Southwestern Naturalist 28:100-102.

Warnock, R. 1996. Spatial, temporal and turnover dynamics of Burrowing Owls in the extensively fragmented grasslands of Saskatchewan. University of Regina, Regina, Saskatchewan. M.S. thesis. 112 pages.

Warnock, R. 1997. Is habitat fragmentation a factor in the decline of the Burrowing Owl in Saskatchewan? Blue Jay 55:222-228.

Warnock, R., and P. C. James. 1996. Effects of habitat fragmentation on Burrowing Owls (Speotyto cunicularia) in Saskatchewan. Page 318 in W. D. Willms and J. F. Dormaar, editors. Proceedings of the fourth prairie conservation and endangered species workshop, Natural History Occasional Paper 23. Provincial Museum of Alberta, Edmonton, Alberta.

Warnock, R. G., and P. C. James. 1997. Habitat fragmentation and Burrowing Owls (Speotyto cunicularia) in Saskatchewan. Pages 477-486 in J. R. Duncan, D. H. Johnson, and T. H. Nicholls, editors. Biology and conservation of owls of the Northern Hemisphere: Second International Symposium. U.S.D.A., Forest Service General Technical Report NC-190, North Central Forest Experiment Station, St. Paul, Minnesota.

Wedgwood, J. A. 1976. Burrowing Owl in south-central Saskatchewan. Blue Jay 34:26-44.

Wellicome, T. I. 1994. Taverner award recipient's report: is reproduction in Burrowing Owls limited by food supply? Picoides 7:9-10. 
Wellicome, T. I. 1997a. Reproductive performance of Burrowing Owls (Speotyto cunicularia): effects of supplemental food. Pages 68-73 in J. L. Lincer and K. Steenhof, editors. The Burrowing Owl, its biology and management: including the Proceedings of the First International Symposium. Raptor Research Report Number 9.

Wellicome, T. I. 1997b. Status of the Burrowing Owl (Speotyto cunicularia hypugaea) in Alberta. Wildlife Status Report No. 11. Alberta Environmental Protection, Wildlife Management Division, Edmonton, Alberta. 21 pages.

Wellicome, T. I., and E. A. Haug. 1995. Second update of status report on the Burrowing Owl, Speotyto cunicularia, in Canada. Committee on the Status of Endangered Wildlife in Canada, Ottawa, Ontario. 23 pages.

Wellicome, T. I., G. L. Holroyd, K. Scalise, and E. R. Wiltse. 1997. The effects of predator exclusion and food supplementation on Burrowing Owl (Speotyto cunicularia) population change in Saskatchewan. Pages 487-497 in J. R. Duncan, D. H. Johnson, and T. H. Nicholls, editors. Biology and conservation of owls of the Northern Hemisphere: Second International Symposium. U.S.D.A., Forest Service General Technical Report NC-190, North Central Forest Experiment Station, St. Paul, Minnesota.

Zarn, M. 1974. Burrowing Owl, report no. 11. Habitat management series for unique or endangered species. U. S. Department of the Interior, Bureau of Land Management, Denver, Colorado. 25 pages. 